\title{
Flood Risk Management in Rivers and Torrents
}

\author{
Luca Franzi \\ Regione Piemonte \\ Italy
}

\section{Introduction}

Among the meteorology-related risks, flooding is one of the first risks which human communities had to cope with in the past. From a historical point of view, the floodplains have been the preferred places for settlement of anthropogenic activities, because of the availability of richer soils, waters supplies, ways for transportation. Even if when speaking of floods and their effects the emphasis is generally placed on destructive forces, historically floods have also been considered as beneficial processes, providing the recharging of water sources, the fertility of soil, carrying nutrients and sediments, and assuring the rejuvenation of the river ecosystem (WMO, 2006). Even if the colonization of mountain regions is more difficult and generally offers less natural resources, evidence shows that also more impervious regions are urbanized, such as the torrent fans. This is as a reflection of a sharp population increase, an expanding economical growth, a great investment in infrastructures. As a consequence, structural control countermeasures have been traditionally placed along rivers and torrents, in the effort to reduce the risks and to assure a total protection against flooding and inundations.

Experience shows that the total protection is a myth (WMO, 2004), either along floodplains or torrents. Actually, due to an inadequate understanding of flood processes, to an increasing quantity and value of the settlements at risk, Flood Risk Management (FRM) strategies which aimed at keeping the floods inside the channels, proved to be unsuccessful.

The main purpose of this chapter is to focus on the different strategies which have been proposed by scientists, and applied by practitioners and decision makers to cope with floods and to manage risks due to inundations by rivers and torrents. The subject is challenging as it involves different disciplines, ranging from hydrology, structural engineering, geology, economy, politics and social sciences. A continuous interchange among the different disciplines is generally needed to find what strategies are best to follow, considering either the positive or the negative effects of flooding, balancing benefits and losses, structural and non-structural countermeasures.

The interest in this subject is double. First of all, flood risk management is a topical subject. Actually the European Union Commission has recently approved the directive on the assessment and management of flood risks, which obliges member States to establish flood risk management plans, coordinated at the level of the river basin districts, "with a view to avoiding and reducing the adverse impacts of floods" and addressing "...all aspects of flood risk management focusing on prevention, protection, preparedness, including flood 
forecasts and early warning systems and taking into account the characteristics of the particular river basin or sub-basin" (European Commission, 2007). The directive is an important step for enhancing the flood risk management practices in European countries.

Secondarily, as mentioned before, FRM requires a strong collaboration of many professionals, which generally work independently. Therefore researchers, technicians, engineers, geologists, sociologists, and politicians are equally involved, together with people. Experience shows that without a strong collaboration and interaction among them, the benefits for endangered populations are not equally distributed, the economical repayment is less, the engineering solutions show to be only moderately effective, politics in risk management prove to be inefficient. The collaboration implies a shared understanding about the risk concept (What's flood risk? Which are its components?) and a shared methodology to manage risk (How can flood risk be assessed, evaluated and treated?).

Therefore, in this chapter, following the approaches proposed in literature, a concept of risk management is proposed, with a presentation of some strategies for its management (Section 2). The aim is to show and discuss what is the state-of-the-art (Section 3), by virtually addressing to the professionals involved in flood risk management, comparing different approaches in FRM, showing the necessity to bring the flood risk management in a common context of scientific, political and public debate, as well as proposing a common understanding of concepts. In particular the concept of flood risk management is introduced as the main concept, instead of the earlier and narrower paradigms of flood defence and flood control. A more in-depth description of the FRM followed in the Northern part of Italy is given (Section 4). It will be shown, in particular, that the effectiveness of the applied strategies strongly depends on the uncertainties in the flood risk assessment. As a consequence, FRM strategies should be enough flexible to adapt to new circumstances and evidences, taking into account a good balance between planning and civil protection strategies.

\section{Flood risk management strategies in literature and history}

Flood risk management (FRM) strategies can be very different. The term itself "strategy" seems to be a simple term and can be defined as the set of activities that aim at influencing the world around us. Notwithstanding strategy research has developed different concepts of strategy. On this subject, history itself shows some representative examples of strategies (Kersting, 2008), often derived from practice, common sense and intuition and many handbooks have been recently published (Pettigrew et al. 2002, Easterby-Smith 2003, Pool et a., 2004) in scientific literature, with a more structured and less empirical approach.

Historically, the first FRM strategy had a style of acceptance of the flooding processes, as something people had just to live with (Kersting, 2008). This is the case of the populations which lived along the Euphtrates, the Tigris and the Nile. People simply built houses on piles to keep safe during floods, or look for safe higher grounds.

A first historical Italian example of FRM strategy debate, can be read in Tacitus (Tacitus, 115 $\mathrm{AD})$, who reports that after the Tevere inundations (15 AD) a debate arose in the Roman senate on the best practices that should have been followed to reduce flood risks. Two strategies were proposed, that is the "do-nothing" one, implying no interventions, and the 
"structural" one, which implied the construction of dams and Tevere diversions. The latter approach prevailed (Tacitus, 115), after a discussion with land owners, which opposed against the damming of the Velino lake, which would have caused the permanent inundation of the surrounding territories. Tacitus reported that a participatory approach in the choice of the best solution was followed by Tiberius emperor, who rejected the proposals based on superstition or sibylline responses.

Historically the early FRM strategies focused on the implementation of flood control countermeasures, and are generally addressed to as "defence strategies" (Stalenberg and Vrijling, 2006). These flood control practices are widely documented during the Renaissance. For example, Coccapani's opera entitled "Trattato del modo di ridurre il fiume Arno in un canale" (Tractate on how to transform the Arno river into a channel, Coccapani, 1610) focused on structural controls of the river, either for reducing the inundation risk in the surrounding agricultural areas or for navigation purposes. In that opera, Coccapani harshly criticized the intervention already made, stating that "fluvial accidents [in Arno river] are not due to natural defects, but mainly to improper interventions, made by inexperienced architects". Also Galileo Galilei (Acanfora, 1990) confirmed that the structural measures to canalise Arno river have been extensively used for river "corrections", for navigation purposes (see Figure 1).

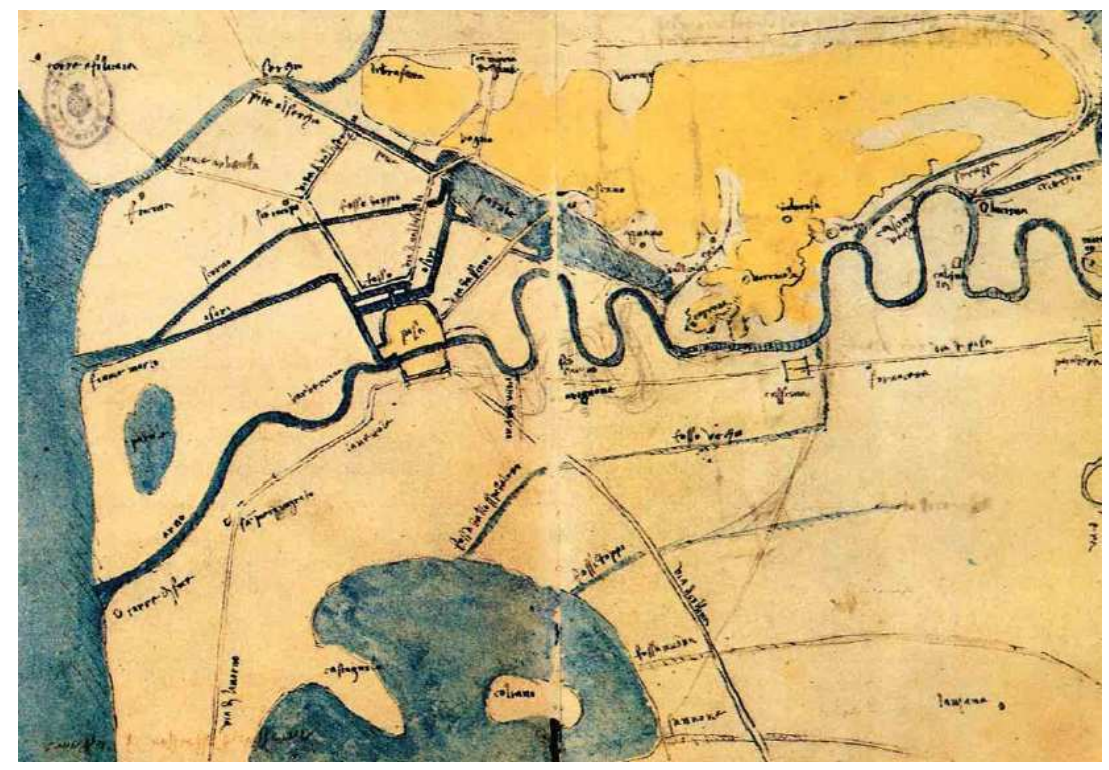

Fig. 1. Map of Leonardo da Vinci (1503), representing the Pisa surroundings and the project of diversions.

In more recent times, the role played in Northern Italy by the protection strategies is documented by the creation of the "Magistrato civile per lavori generali che riguardano il grande sistema del Po" (The civil magistrate for the general works of the Po river system) in 1806, that is a corps of technicians and engineers which were in charge of the maintenance and construction of structural interventions. 
Some hints to the necessity of dealing with trade-off, considering either the hydraulic system, or the social and local administration context, can be found in Paleocapa (Paleocapa, 1868). He was an engineer, member of the Italian Parliament, who proposed a participatory approach to assess the effectiveness of the proposed countermeasures. In particular, Paleocapa claimed that the diversion of Brenta, Bacchiglione and Sile rivers away from the Venice lagoon should have been the result of a trade-off, balancing the necessity to avoid the sedimentation in the Venice lagoon, the expenses to maintain the artificial embankment system, and the reduction of damages in the Provinces which were crossed by the diverted river courses. Paleocapa claimed that those Provinces could not support the economical expenses for the maintenance of the diversion system. Actually, according to him, it was unfair that the Venice lagoon enjoyed the benefits of interventions, while the Provinces had to suffer for the inundations of the diverted rivers and to pay for the maintenance of the embankments.

The strategies of flood defence and of flood control were widely applied even after the Second World War, in Europe, in the 1950s to the 1980s, imposing a strong engineering approach to keep floods inside the river channel or inside lateral embankments. These concepts revealed to be captious, suggesting incorrectly that humans can control nature, influencing processing, according to their finalities.

In the 1990s the concept of flood risk management was introduced in Italy (Po Basin District Authority [PBDA], 2001a; Italian Parliament, 1989), implying that floods are natural phenomena which cannot be prevented and pointing out that some human activities can significantly contribute to increase the adverse impacts of flood events (EC, 2007).

In recent years, probably as a consequence of political debate about floods, the scientific literature gets richer in papers dealing with FRM strategies. The classic definition of strategy given in business economics (Chandler 1962) has been considered to be ineffective (Floodsite, 2005), because FRM strategies generally have to be implemented under conditions of increasing uncertainty (see section 4). Uncertainty itself is a relevant topic for modelling and managing (Sayers et al., 2002; Hall et al., 2003). Therefore other definitions have been proposed, by Universities and private or public Associations and Authorities.

One of the early definition describes strategy as "a consistent set of measures, aiming to influence developments in a specific way"(Hooijer et al., 2004, p.346), a definition that focuses on the content of strategies (i.e., the countermeasures, the general aims and targets, the specific alternatives and so on), without hints to the way the strategy is implemented, to the societal context, to the way the alternatives are balanced and evaluated.

Often the FRM strategy definitions refer to simple daily live expressions, which can be interpreted as an empirical approach, more based on intuition than on systematic investigation. These definitions generally refer to the way of using structural measures, like "do-nothing" strategy, "do-minimum" strategy, "as-low-as-reasonably possible" strategy, "as-more-natural-as-possible" strategy.

By following (Hutter, 2006) and (FloodSite, 2007) and the (PBDA, 2001), strategy is here defined as a "constant combination of long-term goals, aims and measures, as well as a process that is continuously aligned with the social context". At present, either scientific literature (Hutter 
2006, Floodsite 2007) or practice (PBDA, 2001a), consider that a multidimensional understanding of strategy, is needed in FRM, encompassing (Pettigrew and Wipp, 1991):

1. the dimension of the content (deciding what to do) which refers to complex hierarchy of priorities, targets and combination of countermeasures (structural and non-structural) and alternatives, in order to manage risk;

2. the dimension of the context (what the initial and boundary conditions are) where the floods occur; this implies the understanding of conditions which are inside the societal texture (human resources, responsibility, culture etc.) or outside (economics, politics, legal framework);

3. the dimension of the processes (deciding how to do it), which describes how strategies are formulated and how they are implemented; process is about learning how to deal with diverse political interests, cultural attitudes, how unexpected conditions or demands are considered.

It should be also considered that strategic choices are not easily reversible in time. Many resources are needed to change a strategy that demonstrated to be ineffective, especially if it has been applied for a long time. The changes in strategies require fresh resources (human and economical), time, changing power structures, changing habits and way of thinking.

On the other hand, a strategy has to be flexible enough to adapt to new situations and conditions.

\section{Essentials in flood risk management - A discussion of the state-of-the-art}

As mentioned before, the Countries in the European Union are now requested to address to flood risk in a more systematic way than in the past. This implies a different strategy in FRM, as mentioned, from a defense approach to a multidimensional one. In this frame the definitions of concepts is the first step for a shared understanding. Setting common definitions is an important tool to avoid the scientist debate to remain isolated from public and political debates. Without a shared understanding of what we mean by words we use, we are in danger of being misunderstood (Klijne et al. , 2008).

\subsection{Flood, risk and risk-management concepts}

Defining the three terms, i.e. flood, risk and management, is an extensively discussed subject. Many authors and associations propose definitions of their own, (PWDA, 2001; WMO, 2009; FloodSite, 2009; EEA, 2007) but a uniformity in terms use has not been yet reached. Therefore the definitions of the terms used in the following are indicated.

In the EU floods directive, the term "flood" has a precise meaning (EC, 2007):

"the temporary covering by water of land not normally covered by water. This shall include floods from rivers, mountain torrents, Mediterranean ephemeral water courses, and floods from the sea in coastal areas, and may exclude floods from sewerage systems".

In spite of the simplicity of this definition, experience shows that different types of floods can be recognised and categorized in an heuristic way, on the basis of their more recurrent aspects, related to their physical source (rainfalls or storms), the geographic area where they 
occur (valleys and floodplains, or mountains), their dynamic characteristics and the speed of onset.

For the sake of simplicity, and for reasons of symmetry with the study cases that are shown in Section 4, two different processes are here described, that are generally addressed to as river floods and alluvial flooding due to flash floods.

As it is well known, river floods origin in plane areas, in valleys, and are characterised by a low velocity of onset. The flood is mainly caused by water, over-topping the lateral protections or gradually inundating the valley, with a concentration of fine-grained sediment, which is mainly transported in water suspension and, to a less extent, on the river bed itself. Lowland floods tend to inundate large areas than floods in upland areas and generally are more lasting. They result from prolonged rainfalls over larger areas, carried by advective clouds and associated with warm or cold weather fronts.

Flash floods can occur in mountainous regions during intense rainstorms, in small catchments up to several square kilometres with steep slopes, impermeable surfaces or saturated soil; they are characterised by high flood water velocity and by a rapid onset, causing floods within a few hours or less. The onset velocity leaves little time for warning and evacuation, especially in the fan areas, which are generally the most urbanised and where there is the highest concentration of receptors. Therefore, the timely prediction of flash floods is the main challenge. Flash floods and, consequently, the alluvial fan inundations, are difficult to forecast, and the risk management is often a very difficult task.

Floods are natural processes, except for the cases where they are man-induced (like in the case of floods caused by dam failures), and do not necessarily imply risks. Intuitively, as far as rivers and torrents are concerned, risk can be defined as the potential loss, due to hazardous phenomena and processes, which generally can be forecast in real time conditions, or within a short time.

By a more technical viewpoint, the following definition is assumed (WMO, 2009) for flood risk:

"potential losses associated with a hazard or an extreme event to a given place within a given period of time, which can be defined in terms of the adverse consequences (damage/losses) and the probability of occurrence".

Therefore the concept of risk necessarily implies the concept of loss, of the probability of flood occurrence, the intensity of the phenomena, the damages that can be produced by the natural event and the vulnerability of the anthropogenic context.

As far as losses are concerned, it is a useful approach to distinguish between direct and indirect losses (Penning et a., 2000). Direct flood losses are mainly due to the immediate physical interaction of flood with anthropic elements, humans, property and the environment. Indirect flood losses are damages caused by disruption of physical and economic linkages of the economy and the extra costs of emergency, such as the emergency countermeasures that are taken for civil protection aims. At least six different components should be taken into account: 
1. the loss of lives, meanly of people living in the floodplains or on in the alluvial fans;

2. the physical damage, that is the loss of functionality of the anthropogenic structures, such as houses, bridges, levees, roads, dams, etc.;

3. the psycho-social impact, that is the psychological effects on people affected directly or indirectly by the flood due to the loss of property or of livelihoods, the displacement from one's home, the disruption of economical, family and social affairs;

4. the functioning disruption, that is the interruption of the interconnections among people, services and webs, so that also people and economical activities that are far from the place where the flood event occurred, suffer for effects of the breaking of interconnections; this is the case, for example, of oil pipelines, water pipelines, railways;

5. the economical impact, that is the hindering of economical growth and development, that is due to the high cost of relief and recover, which may adversely impact investments in infrastructure and the development activities in the area; generally either private and public sectors are discouraged to investments in high recurrent flooding conditions;

6. the economical cost for the emergency countermeasures taken for civil protection aims and other actions taken to prevent flood damage and other losses.

In terms of logical understanding of risk, according to the definition given above, risk can be considered as the combination of three factors, according to the logical formula (UNDRO, 1980; Varnes, 1984; PBDA 2001a, Klijn et al., 2008):

$$
\text { Risk }=\mathrm{H} \times \mathrm{V} \times \mathrm{E}
$$

where $\mathrm{H}$ indicates the hazard, $\mathrm{V}$ the vulnerability and $\mathrm{E}$ the exposure.

This expression indicates that risk, in natural disasters due to flood, can be expressed as the non-linear combination of three factors, that are hazard, vulnerability and exposure (figure 2).

The expression (1) has not to be strictly considered as a mathematical formula. It expresses the idea that, in risk assessment, three factors superpose in a non linear way. Risk factors can be defined in the following way:

- hazard: "the probability of occurrence, within a specific period of time in a given area, of a potentially damage natural process" (UNDRO, 1984), with a specific intensity; the intensity is expressed by referring to a specific scalar or vector quantity or to a graduated scale; in floods generally engineers and practitioners refer to the return time period, that is the is the inverse of the probability that the event will be exceeded in any one year; flood velocities and water depths are generally the physical quantities by means of which the hazard is expressed, while, when sediment transport processes are more relevant (like in the case of alluvial flooding on debris fan), the total deposited sediments or the maximum energy of the water sediment flows are generally addressed to;

- vulnerability: "the degree of a loss to a given element at risk, or set of such elements resulting from the occurrence of a flood with a given intensity", (UNDRO, 1984); vulnerability is a function of the hazard level;

- exposure: "elements at risk, or receptors, that is people, properties and goods that can be lost, injured or damaged during an event" (UNDRO, 1984); also in this case the numbers and types of the elements at risk vary according to hazard level. 
As stated before, the analysis of the exposure should also consider all the indirect factors that contribute to amplify the total losses, i.e. the direct and indirect effects on society, economy and psychology. Obviously, reduction or increase of each factor (Figure 2), implies reduction or increase of risk itself (WMO, 2009).

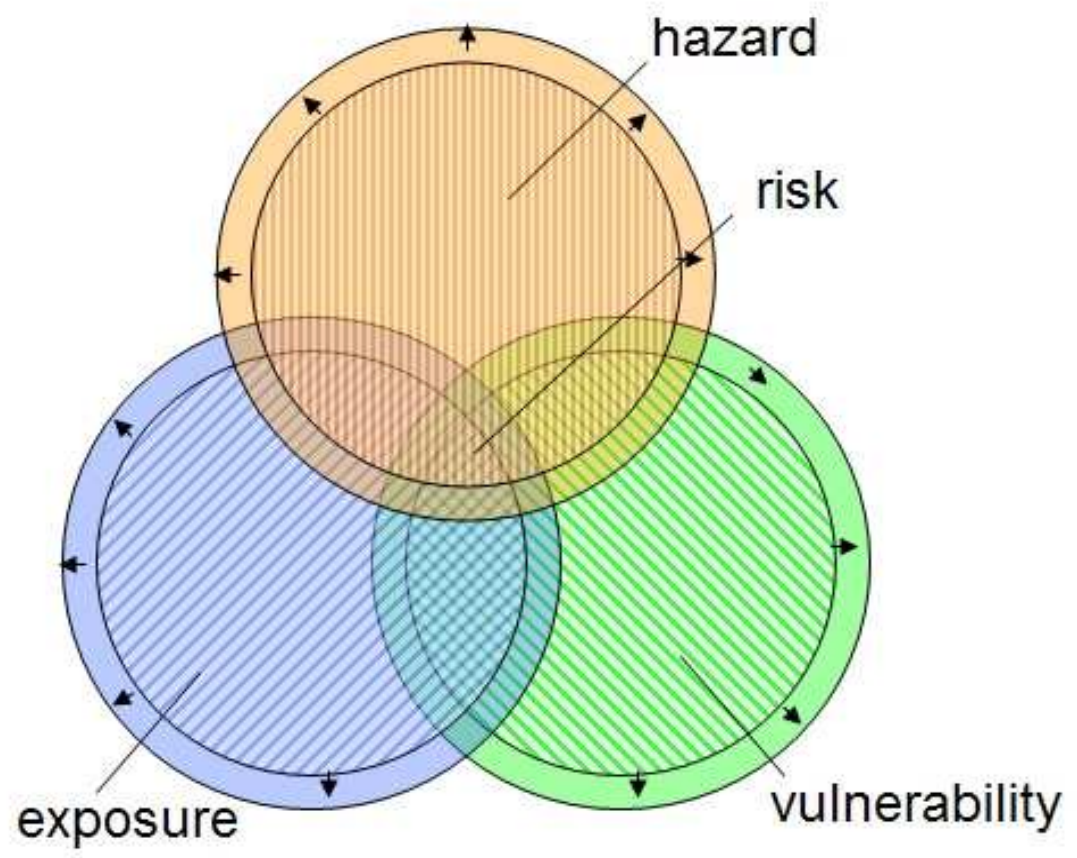

Fig. 2. Elements composing the risk, defined as the superposition of hazard, exposure and vulnerability. The arrows indicate the effect on risk due to an increase in hazard, vulnerability, exposure (WMO, 2009).

Flood risk has dual dimensions, that is objective (physically measured) and subjective (socially-evaluated). The former, which lay in domain of the scientific investigation, shows a high variability in the natural and physical processes which occur in rivers and torrents, in different climatic conditions. The latter is due to the fact that (i) risk affects different people differently; (ii) impacts of risk may cross the territory; (iii) risk perception and concern is different from person to person and from community to community, due to their different thinking, feeling and action; (iv) needs for and capacity of risk reduction are different from person to person.

These topics have to be carefully taken into account by decision makers when they discuss what measures are best to take in the risk management. This latter concept - risk management - can be defined as the "Coordinated activities to direct and control an organization with regard to risk" (ISO, 2007). In this chapter, we consider that risk management includes risk assessment, risk evaluation and risk treatment, defined as indicated in table 1 . These three components are discussed in the following. 


\begin{tabular}{|c|c|c|}
\hline Concept & Definition and reference & Other references \\
\hline $\begin{array}{l}\text { Risk } \\
\text { Assessment }\end{array}$ & $\begin{array}{l}\text { "Risk Assessment means a process or method for } \\
\text { evaluating risk associated with a specific hazard and } \\
\text { defined in terms of probability and frequency of } \\
\text { occurrence, magnitude and severity, exposure, and } \\
\text { consequences" (FEMA, 1997) }\end{array}$ & $\begin{array}{c}\text { (Environmental } \\
\text { protection } \\
\text { Agency 1986; } \\
\text { DOT, 2005) }\end{array}$ \\
\hline $\begin{array}{l}\text { Risk } \\
\text { Evaluation }\end{array}$ & $\begin{array}{l}\text { "Establishment of a qualitative or quantitative } \\
\text { relationship between risks and benefits, involving } \\
\text { the complex process of determining the significance } \\
\text { of the identified hazards and estimated risks to those } \\
\text { organisms or people concerned with or affected by } \\
\text { them." (EEA, 2007) }\end{array}$ & $\begin{array}{l}\text { (European } \\
\text { Environment } \\
\text { Agency, 2007; } \\
\text { DRJ \& DRII, } \\
\text { 2007; WMO 2009) }\end{array}$ \\
\hline $\begin{array}{l}\text { Risk } \\
\text { Treatment: }\end{array}$ & $\begin{array}{l}\text { "Process of selection and implementation of } \\
\text { measures to modify risk." (ISO, 2007) }\end{array}$ & (WMO, 2009) \\
\hline
\end{tabular}

Table 1. Definitions of the different phases of risk management.

\subsection{Risk assessment}

In risk assessment, all the components which are intrinsically and technically connected to risk are considered, that is the flood hazards, the vulnerability and the exposure. A principle of risk assessment is that it is better to be roughly right than exactly wrong. In particular this is evident in the flood processes which can only be roughly predicted, like in the case of alluvial fan inundations (see also Section 4). Risk assessment includes different basic steps, that can be summarised as follows:

- estimation of the hazard, according to its technical definition, and including the location, frequency and severity of the flood;

- estimation of the exposure, evaluating the number of people, buildings, factories, cultivations etc. exposed to the hazard; these are generally called elements at risk or receptors;

- $\quad$ estimation of the vulnerability of the elements at risk and receptors, which is usually expressed as percentage losses of people, buildings, cultivations, etc.;

- $\quad$ superposition of the hazard, exposure and vulnerability.

Estimation of the different factors affecting risks is generally a challenge for technicians, practitioners, public administration and researchers alike. A complete discussion of the risk components would imply a deep understanding of the natural hazardous processes, of statistics, economy and of geology, engineering matters, so that just some hints can be given here as far as the estimation of hazard, exposure and vulnerability are concerned.

\subsubsection{Estimation of the hazard}

According to the definition above, flood hazard should be defined by means of a complex system of probabilistic, or deterministic, modelling approaches. As far as the flood hazards in rivers are concerned, the main steps are the following (PBDA, 2001a; Klaus et al., 1994): 
- determination of the design flood at a give location, by means of the regression of available data (direct methods) or by means of modelling the hydrological processes (indirect methods);

- hazard mapping, that is the mapping of the extent of areas that can be flooded by the design discharge;

- hazard ranking, that is the mapping of the areas with different hazard levels; this can be done by addressing to depth, duration of the floods or to the velocity of water.

When the analysis is performed to assess the hazard in areas protected by embankments or levees, it should also be assessed the reliability of the defence structures in relation to different loading conditions, particularly from the pressure or impact of the flood on the defence structures. At its turn, this reliability is strongly dependent on the maintenance state, the structure age, and it is in general a source for uncertainty (Vrijling and Gelderr, 1997; Merkel and Westrich, 2008).

The described methodology for risk assessment, which appears to be simple in principle, suffers from many uncertainties that generally stem from different sources. Hazard assessment uncertainties can be divided into the following main groups.

- Knowledge uncertainties. These uncertainties that come from basic lack of knowledge, so that many phenomena can be only roughly understood and simulated; this is the case of the triggering mechanics of flash floods, or the morphological changes induced by floods during an event.

- Input and parametric uncertainties in modelling. When mathematical models are applied, it should take into account that the computed results are obtained for particular simulation conditions, i.e. for given inputs and set of parameters. A different choice of inputs or a different set of parameters (Kuczera and Mroczkowski, 1998; Beven and Freer, 2001) influences the results. For example, as far as design discharge is considered, it should be considered that flood probability estimation is generally based on a statistical regression of available data, which often show to be statistically inconsistent (see Section 4 for the Dora Baltea study case); moreover, the statistical methods generally assume the stationary (figure 3) of the flood formation processes (see below).

- Calibration uncertainty in modelling. It is generally due to the criteria which is adopted for model calibration, especially in flood modelling; generally the "optimization" criteria are arbitrarily assumed (Beven and Freer, 2001).

- Structural uncertainty. It is an inherent feature of the applied model: it is a consequence of the simplifying assumptions made in approximating the actual environmental system with a mathematical hypothesis.

As hinted above, flood hazard assessment is generally made by assuming stationarity, that is by assuming that the river basin remains the same in time, while, in reality, the physical characteristics of the basin or of the river valley change in time (Figure 3). Variations in time of soil use (man-induced or natural, like vegetation) of topography and of rainfall regime (even without considering relevant climate changes; Arcilla, 2007) can alter the way in which floods originate (Ducrocq, 2008) or are conveyed through the valley. The key message that should be taken into mind by decision makers is that the past cannot be the sole guide to the future. 

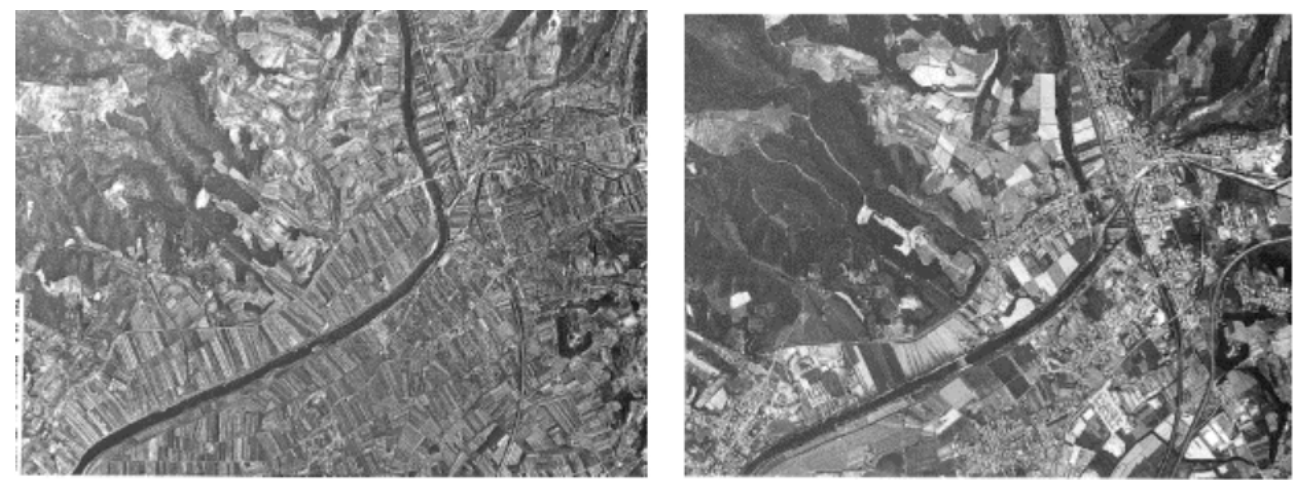

Fig. 3. Aerial pictures of Arno river (Italy) near Montelupo Fiorentino in the period 1954 (left)-1993 (right). Urbanisation that took place especially during the fifties and the sixties, substantially increased the number of receptors along rivers and altered the processes of formation and propagation of floods along watercourses (Autorità di Bacino del fiume Arno, 1997).

When the modelling uncertainties do not allow us to obtain results within reasonable tolerances (Figure 4), generally more heuristic approaches are followed for example with the help of empirical evidences. In particular, risk assessment in alluvial fan flooding is affected by stronger uncertainties (see Section 4). In these cases a detailed back-analysis is a basic step to estimate (even roughly) the order of magnitude of the hazards, by means of the reports recorded in newspapers, geomorphological or statistical approaches (Franzi and Bianco, 2000).

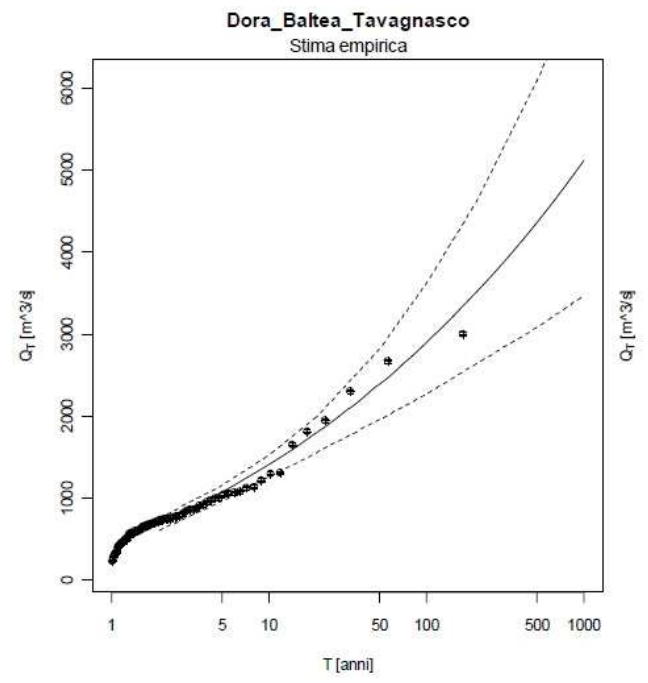

Fig. 4. Confidence intervals of quantiles. The data refer to Dora Baltea river (Italy). The variability in the assessment of discharge (dotted lines) which corresponds to a given return period can be easily read on the figure. (Claps et al., 2008). 


\subsubsection{Estimation of the vulnerability}

Generally speaking, vulnerability is the proneness of structures, goods, humans, communities to be impacted by flooding (UNDRO, 1984). Therefore vulnerability represents the inadequacy of structures, or the incapacity or inability of a community to resist and/or recover from the impacts. This inadequacy or inability can play an important role in the transformation of a hazard into a disaster.

According to the element at risk (inhabitants, structures, communities), a different vulnerabilities should be considered, as every element can react to and recover from floods in a different way. The total vulnerability is the combination of the complex interconnections among communities, individuals and structures and their capabilities to cope with disasters. The factors influencing the vulnerability are mainly the following:

- physical/material conditions: related to the kind and quality of material of constructions and to the physical state of people that can be involved in the floods;

- organizational: related to the way in which communities are managed, structured, interconnected;

- $\quad$ attitudinal: related to culture, awareness.

In table 2, these factors are briefly listed an analysed (WMO, 2006).

Physical/material

Infrastructures, houses, farms, humans,
Vulnerability factors Vulnerable elements

Source for vulnerability

Weak infrastructures / Wrong design

Materials inadequate for the design

floods

Lack of maintenance works

Physical degradation of materials

Unpreparedness / Unawareness

Malnutrition, disease, handicaps, age

Lack of leadership, or organizational structures

Organizational Communities

Lack of representation

Spot aids without a central management

Scarce preparedness of civil protection

Lack of information to people

Lack of the awareness of rights and

obligations

Attitudinal Humans, communities

Heavy dependence on external support

Table 2. Vulnerability sources, for different kinds of receptors.

Considering that vulnerability factor can be quantified by values between 0 (invulnerable receptors) and 1 (totally vulnerable receptors), some technical detailed approaches have been proposed in literature for vulnerability quantification (Green et al., 1994). Due to the complexity of the different factors and scales on which vulnerability depends, the attempt to include also structural, durability, resilience, robustness factors to model all the vulnerability components, generally results in a higher complication of methods. In the 
flood management plan that is now in force in Italy, the vulnerability has been simply ranked into classes, as shown in table 3 (PBDA, 2001a). This approach is an oversimplification of the reality, but it proves to useful in many cases.

\begin{tabular}{|c|l|}
\hline $\begin{array}{c}\text { Vulnerability } \\
\text { classes }\end{array}$ & Items can be damaged \\
\hline V1 & Elements at risk can undergo minor level functional damages \\
\hline V2 & Elements at risk can undergo medium level functional damages \\
\hline V3 & Elements at risk can be destroyed or severely damaged \\
\hline V4 & Elements at risk are certainly destroyed or severely damaged \\
\hline V5 & $\begin{array}{l}\text { Elements at risk are certainly destroyed or severely damaged and } \\
\text { there is the possibility that human life can be lost }\end{array}$ \\
\hline
\end{tabular}

Table 3. Vulnerability classification according to Italian legislation (PMC, 1990).

\subsubsection{Estimation of the exposure}

The concept of exposure refers to all elements at risk (receptors), that is people and properties that can be lost, injured or threatened by a hazard. Assessment of exposure has to consider its dependence on the hazard levels, the variability of exposure in time (especially in urbanized areas, where the soil use destination can change rapidly in time) and the uncertainty in its determination.

The most useful procedure consists in establishing the total number and kind of receptors that may be hit by a flood, that is the degree of exposure.

Identification of receptors, for different hazard levels, is therefore a central point, and one common way of achieving this is to produce an overlay of the receptors, eventually with the help of Geographic Information Systems (GIS).

As far as people are concerned, data must be collected on the number of people who reside, work or travel in the area liable to flooding, together with their demographic characteristics, as these affect their personal vulnerability. These data can often be obtained from national censuses, municipalities, local administrations databases. Field surveys and data on industrial and commercial enterprises can help to have a better estimation of people working in the exposed areas. Assessing the number of people who travel through the area liable to flooding may need special surveys or data from state transport departments.

As far as property is concerned, data are needed on the number and location of different types of property (houses; factories; etc), as well as on their value and their susceptibility to flooding. Moreover all kinds of properties should be collected and surveyed, that is economical properties and activities, State properties, like bridges roads, but also aqueducts, drinkable water wells, pumping stations, and cultural properties, like national libraries, museums. Cultural receptors should not be underestimated, as the social capacity to recover after a flood also depends on personal losses and on the loss a cultural heritage (Figure 5). 

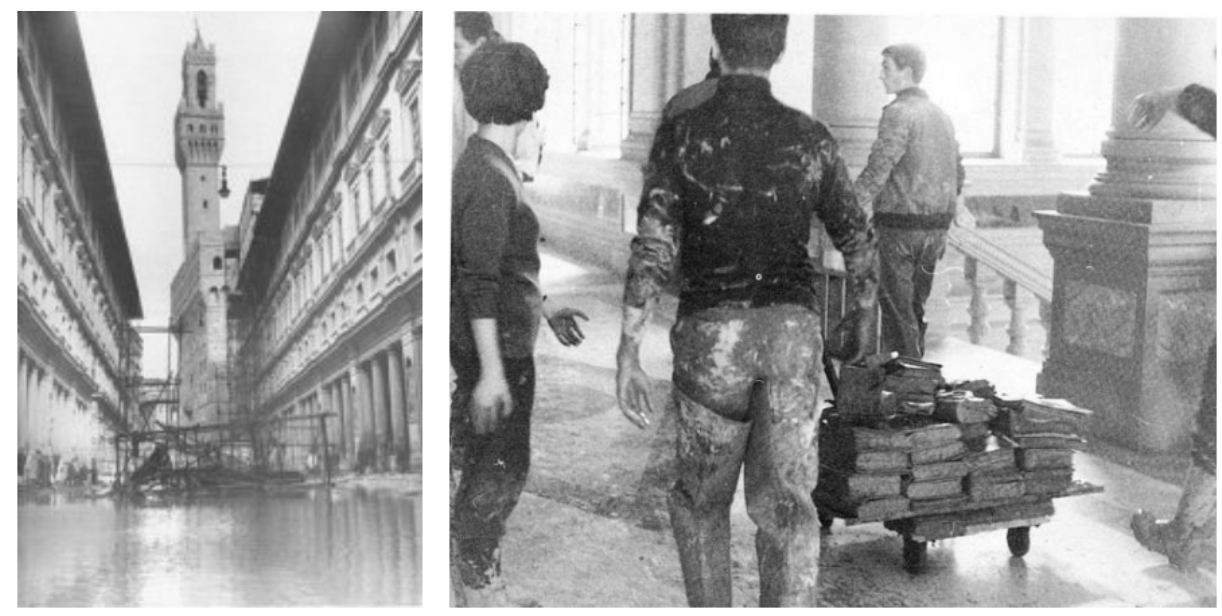

Fig. 5. Florence flooding in 1966, November $3^{\text {rd }} 4^{\text {th }}($ left $)$ and the so-called "mud angels" (right), that are students and volunteers that helped to move the artistic works of art and to recover books during and after flooding.

Similarly, as environment can be considered a property, the exposure of habitats and species should also be considered, especially when dispersed pollutants can adversely affect floodplain ecology and ecosystems.

There are two principal ways to obtain this required land use information: by carrying out field surveys (primary data) or, more usually, by relying on existing land use data (secondary data).

The advantage of primary data is that all required land use and property information can be collected at the level of detail that is needed. On the contrary, field surveys are timeconsuming and costly, whereas secondary data, such as national censuses of land use, are often readily available. The main disadvantage of secondary data is that they are not produced for the purpose of flood risk assessment (often they are collected for local property taxation purposes) and, therefore, they probably not contain all necessary information at the required level of detail. Moreover secondary data can reveal to not be updated.

Obviously, the total number of receptors which can be hit by flooding varies according to the hazard level, including the probability of failure of the structural countermeasures which should avoid flooding.

\subsection{Risk evaluation}

Risks assessment is generally the product of the collaboration among scientists, practitioners, engineering, economics and people, and its contents are more technical than decisional. After risk assessment, risk management should focus on establish what are the acceptable and tolerable risks levels. By considering that total protection against risk or the total elimination of hazard is impracticable from a economical point of view and scientifically unfeasible, decision makers should establish what is or what are the risk levels 
at which risks are still acceptable or tolerable. This implies subjective and objective assessment.

In the flood management plan in Italy (PBDA, 2001a) this concept has been efficiently expressed throughout the notion of "compatible risk" which is here reported, as follows:

The compatible risk specifies and plans out what are the hydraulic and geological risk conditions that should be residual at a basin scale. Its assessment depends on the social and economical expectations for protection(...). The gap between present risk and compatible risk implies the necessity of the implementation of countermeasures.

Tolerability and acceptability are the two main concepts which have to guide the evaluation of the flood risk. The key idea is that some risks can result to be unacceptable, but can be still tolerable by society, by a local community or by individuals. Predictably, each alternative solution will present some internal conflicts between locally acceptable levels of risk and socio-economic (UNDRO, 1979).

The approach to tolerable/acceptable risks is known as ALARP principle (Floodsite, 2009), and involves the definition of (Figure 6):

- an upper bound risk level above which the risk is no more acceptable (level of maximum tolerability);

- a lower bound risk level (individual or societal) below which risk is not a concern (level of acceptability);

- $\quad$ an intermediate region, i.e. a tolerability region, where societal and individual risk reduction is required to achieve a level "as low as reasonable practice".

From a social science point of view, the upper and lower limits of tolerability region may differ significantly between persons, among individuals and society. A public consensus on risk acceptance may not exist.

Moreover the determination of the tolerability and acceptability of risk implies the determination of:

- the individual acceptance - that is an analysis of the socio-economical concerns and of the risks perceptions, which are mainly linked to the attitude of people in endangered areas, to their past or recent experience, to the past or recent psychological stress caused by flood events; (UNDP- DHA 1994);

- of the expert acceptance - that is an analysis of the effective situation, evidencing the effective level of risk and the possibility to recover from a flood; the expert acceptance has to be the result of the application of economic principles, laws and safety norms.

All people, whether aware or unaware of the actual flood risk they run individually, have their own rationality, and this is not necessarily the same as that of the scientist or the flood risk manager. In general, a correct approach should not rank individual acceptances as "correct" or "not correct", as individuals perceptions are different.

However it should be clear that either in "expert" or in "individual" perception of risk, humans tend to believe and think about risks with less precision than they really have. 


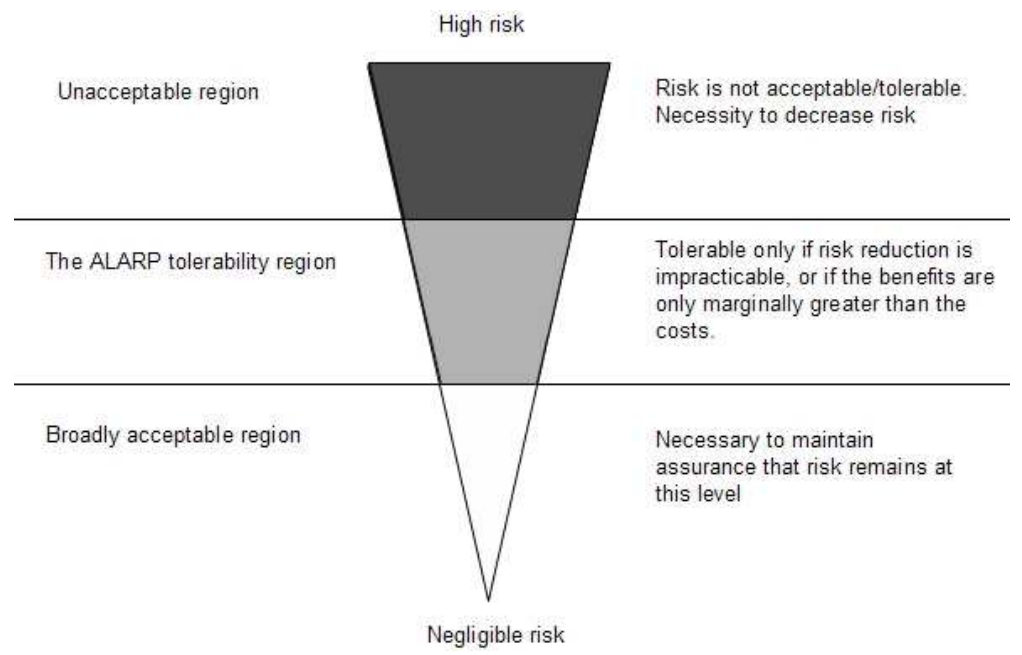

Fig. 6. Sketch of the ALARP principle (Floodsite, 2009).

In order to allow a comprehensive assessment of risks, risk evaluation should elaborate risks scenarios, that is individuate and represent the more significant situations for every level of risks. In this frame, the capacity to simulate different situations, and the availability of flexible analysis instruments can strongly influence the capacity to let a better understanding of the consequences of flooding.

For example in the Po river basin, it is well known that floods peaks reduction can be strongly influenced by the extension of flooding in the upper parts of the watershed basin, that is in the North-western areas of Italy. In general, the larger is the flooding extension in the upper part of the Po basin, the stronger is the reduction of flood peaks of downstream discharges. The physical process which causes a decrease in hazard level, is known in literature as peak discharge lamination and it is a positive effect of flooding. In order to understand what should be the optimum in the flooding extension, different scenarios have to be theoretically developed, between to following extreme conditions, that, for the sake of simplicity, can be described as follows:

- it is maintained and enhance a high protection levels for existing receptors in the upper part of watershed, by means of levees, embankments and floodwalls, limiting lamination of the flood; as a consequence, receptors in the lower part of the watershed could experience a risk increase, due to higher peak discharges and flood levels;

- it is maintained and enhanced a high protection levels for existing receptors in the lower part of the watershed, by means of enhancing large inundations in the upper part, in order to increase flood lamination; receptors in the upper part should experience a risk increase do to the lack of defences and more frequent flooding.

What should be the "best" solution between the two, that is the optimal extension of inundations, is a subject of risk evaluation through different scenarios.

In risk evaluation a social and economical cost effectiveness analysis should be performed, in order to separate what is feasible from an economical and technical point of view from what 
it is not. This allows the establishment of priorities and, implicitly, the risk level that is residual after the implementation of countermeasures.

Some of the most used methods in cost-effectiveness analysis are the cost-benefit analysis (which is indicated in literature with CBA) or the multi criteria analysis (MCA). Some indications about these methods can be found in literature (WMO, 2007) and are not considered here.

\subsection{Risk treatment}

The strategies in flood risk treatment can range from risk reduction (prevention and protection), risk transfer and risk retention, that can be described as follows (Table 4).

- $\quad$ Risk reduction (including prevention and protection). It is a common way to cope with risk, and includes all the measures that reduce the three factors which risk is made of, that are the hazard, the exposure and the vulnerability, mainly by means of flood protection and flood prevention countermeasures. Risk protection generally refers to the hazard reduction, and to the traditional methods in civil engineering interventions. Risk prevention generally includes all the actions that aim at the vulnerability and exposure reduction, without influencing the flood dynamics. Risk reduction countermeasures can be classified into structural and non structural, as it is discussed below (PBDA, 2001a).

- Risk transfer (or sharing). In this case risk in transferred to assurance companies, by means of a insurance policy; in risk transfer people can temporarily suffer for the economical loss, but they can recover in the medium period by means of the monetary refunding. Obviously some losses cannot be totally transferred, so that risk transfer in these cases is just a monetary compensation. The basic principle is to spread the risks over time, and among individuals, organisations or government, which pay insurance premium against a specific flood risk level (WMO, 2009).

- Risk retention. In this case people live together with risks, with or without preparedness, being or not aware of the presence of risk. Since risk cannot be completely eliminated and the total protection is unfeasible, residual risk forces people to live in conditions where the probability to have losses is not equal to zero. Residual risk can be defined as "the risk that remains after risk management and mitigation". As residual risk is retained, people should be preliminary informed about the risks they can experience and should be informed how to eventually cope (individually or collectively) with risks, especially in collaboration to civil protection agencies.

Risk reduction countermeasures can be classified into structural and non structural (PBDA, 2001a).

Structural countermeasures have been extensively used in the past, and they are the most traditional tools to cope with floods (WMO, 2004, 2005; PBDA, 2001a). The approach is that of tradition civil engineering, that is based on construction of permanent concrete/steel/stony structures to protect from floods. Generally structural measures focus on the reduction of flood hazard, by reducing the flood magnitude, the flood extension or decreasing the vulnerability of receptors. A classification of structural countermeasures can be made by referring to their extension, that is intensive, if located along or across rivers, or extensive, if diffusely spread all over the basin (Table 4). 


\begin{tabular}{|c|c|c|}
\hline $\begin{array}{l}\text { Risk treatment } \\
\text { strategy }\end{array}$ & Instruments & Example of countermeasures \\
\hline $\begin{array}{l}\text { Risk reduction } \\
\text { (prevention } \\
\text { and protection) }\end{array}$ & $\begin{array}{l}\text { Structural and non } \\
\text { structural measures. }\end{array}$ & See table 5 . \\
\hline Risk transfer & Insurance policy & $\begin{array}{l}\text { Policy for mandatory/voluntary insurances } \\
\text { against natural disasters }\end{array}$ \\
\hline Risk retention & $\begin{array}{l}\text { Living with risk } \\
\text { Emergency plans } \\
\text { Civil protection } \\
\text { countermeasures }\end{array}$ & $\begin{array}{l}\text { Preliminary to flood: } \\
\text { Information about the kind of risks;; } \\
\text { implementation of water proof defence } \\
\text { implementation of civil protection plans } \\
\text { When flooding is imminent } \\
\text { Detection of flood formation } \\
\text { Forecasting of flood discharges by means of } \\
\text { modeling } \\
\text { Early warning/warnings dissemination } \\
\text { Warning confirmation } \\
\text { Response (Closure of roads and bridges, } \\
\text { operation of barriers, provision of } \\
\text { temporary flood protection measures), } \\
\text { evacuation, rescue } \\
\text { Post-flood actions }\end{array}$ \\
\hline
\end{tabular}

Table 4. Strategies in risk treatment.

At present, the necessity to take structural countermeasures in flood management, is often a consequence of urbanization and of the flood management strategies followed in the past. Historically the enhancement of protection against floods favored the occupation of floodplains, increasing the total number of receptors potentially at risk. At the present state, the necessity to maintain the economical activities on floodplains as well as the need to protect urban areas, force local authorities to implement, and even expand and extend the present systems of structural protection countermeasures.

Structural countermeasures have to be technically feasible and economically reasonable, cost-effective, and sustainable.

Non structural countermeasures do not aim at affect directly the physics of flood process, but they influence the vulnerability and the exposure to flood. The implementation of non structural countermeasures should be the consequence of regulation, of the application of laws and directives. 


\begin{tabular}{|c|c|c|c|c|}
\hline $\begin{array}{l}\text { Classification of } \\
\text { countermeasures }\end{array}$ & $\begin{array}{l}\text { Functionality of the } \\
\text { countermeasures }\end{array}$ & Type of countermeasures & Protect-ion & $\begin{array}{l}\text { Prev- } \\
\text { ention }\end{array}$ \\
\hline \multirow[t]{6}{*}{$\begin{array}{l}\text { Intensive structural } \\
\text { countermeasures }\end{array}$} & $\begin{array}{l}\text { Transversal protections, } \\
\text { against bed erosion }\end{array}$ & $\begin{array}{l}\text { Channel stabilisation works, } \\
\text { weirs, dikes }\end{array}$ & $x$ & \\
\hline & $\begin{array}{l}\text { Longitudinal protections } \\
\text { containing flooding }\end{array}$ & $\begin{array}{l}\text { Levees, flood walls, } \\
\text { embankments }\end{array}$ & $x$ & \\
\hline & $\begin{array}{l}\text { Stabilization of } \\
\text { riverbanks, against } \\
\text { lateral erosion }\end{array}$ & $\begin{array}{c}\text { Rock, concrete, composite } \\
\text { revetments, } \\
\text { gabions or geotextiles revetments, } \\
\text { ripraps, groins. }\end{array}$ & $X$ & \\
\hline & $\begin{array}{l}\text { Maintenance of bed river } \\
\text { profile as and } \\
\text { conveyance }\end{array}$ & $\begin{array}{l}\text { Sediment excavation, artificial } \\
\text { aggradations, river training } \\
\text { (straightening, widening } \\
\text { deepening, hard-lining), removal } \\
\text { of structural operas with negative } \\
\text { impacts / are incompatible } \\
\text { / show to be anomalous with the } \\
\text { flood management plan }\end{array}$ & & $X$ \\
\hline & $\begin{array}{l}\text { Diverge or reduce flood } \\
\text { discharge }\end{array}$ & $\begin{array}{l}\text { Sluices and flood control } \\
\text { channels, detention ponds, dams, }\end{array}$ & $X$ & \\
\hline & $\begin{array}{l}\text { Reducing the flood } \\
\text { peaks }\end{array}$ & $\begin{array}{c}\text { Reservoirs, retention polders, } \\
\text { creation of temporary storage } \\
\text { areas. }\end{array}$ & & $X$ \\
\hline \multirow[t]{2}{*}{$\begin{array}{l}\text { Extensive structural } \\
\text { countermeasures }\end{array}$} & $\begin{array}{l}\text { Interventions aiming at } \\
\text { influencing the flood } \\
\text { formation mechanics }\end{array}$ & $\begin{array}{c}\text { Renaturation } \\
\text { Maintaining or increasing the } \\
\text { total areas of the natural flooding } \\
\text { areas }\end{array}$ & & $\begin{array}{l}X \\
X\end{array}$ \\
\hline & & $\begin{array}{l}\text { Reforestation of hill slopes, soil } \\
\text { use to reduce the total runoffs or } \\
\text { increasing the duration of the } \\
\text { rainfalls runoffs processes, } \\
\text { increasing the infiltration and } \\
\text { retention capacity of the soils, } \\
\text { river rehabilitation; }\end{array}$ & & $X$ \\
\hline \multirow[t]{4}{*}{$\begin{array}{l}\text { Non structural } \\
\text { countermeasures }\end{array}$} & $\begin{array}{l}\text { Real time flood prevision } \\
\text { and communication }\end{array}$ & $\begin{array}{c}\text { Evacuation of the total number of } \\
\text { people at risk; roads and bridges } \\
\text { closure, }\end{array}$ & $x$ & $X$ \\
\hline & Regulation of soil use & $\begin{array}{l}\text { Regulation, laws and acts, Flood } \\
\text { Hazard Zoning, building } \\
\text { regulations on constructions, } \\
\text { technical layout of installations; } \\
\text { regulations on timely evacuation. }\end{array}$ & & $X$ \\
\hline & Flood surveillance, & $\begin{array}{l}\text { Real time control of the } \\
\text { functionality of the defence } \\
\text { system, including levees }\end{array}$ & & $X$ \\
\hline & Ordinary maintenance & & & $x$ \\
\hline
\end{tabular}

Table 5. Structural and non structural countermeasures. 


\section{Planning in flood risk management}

The necessity to implement FRM plans, stems from the definition which has previously given in section 2, abut the three dimensions of strategy. As it has been widely debated in Section 3 , risk assessment, evaluation and treatment phases can allow an appropriate understanding:

- of the actions needed to manage the risk (the content dimension of the strategy),

- of the human resources, of the economical, societal conditions of the endangered areas (the context dimension of the strategy).

Plans are defined in the following way (DHS, 2008): “a plan is a continuous, evolving instrument of anticipated actions that maximize opportunities and guide response operations. Since planning is an ongoing process, a plan is an interim product based on information and understanding at the moment, and is subject to revision". In this frame, the plan can be roughly considered as a tool to describe how the contents of the strategy are formulated and implemented in a given watershed basin. According to the European directive, the aim in planning is the "reduction of potential adverse consequences of flooding for human health, the environment, cultural heritage and economic activity, and, if considered appropriate, with non-structural initiatives and/or on the reduction of the likelihood of flooding" (EC, 2007).

At framework level, we think planning can be fashioned in different ways (see also Floodsite, 2007; PBDA, 2001):

1. the classic mode of programming, which is appropriate under conditions which are highly predictable; this is the case when a plan indicates the amount of economical investments and their chronology, to implement countermeasures, in a given area, in a given time interval;

2. the scenario based planning, which considers different possible futures; it is appropriate when the flood risk conditions can be predicted reasonably well, in a given watershed;

3. the preparedness strategies, increasing organizational activities for coping with the unexpected conditions; this strategy is predominant when the uncertainties do not allow a reasonable and appropriate understanding of the risk.

By referring to the content of plans, they should address all phases of the flood risk management cycle (Figure 7) but focusing particularly on (see also 2007/60 EU directive):

- programming the preventing countermeasures, including maintenance and watch (long term);

- flood event management, containing all the activities that should be carried out to reduce the impact of the floods, when flooding is imminent or already taking place;

- civil protection measures, that is the activities that should be carried out after flooding; the extent of these activities strongly depend on the resilience of the anthropic system, that is the "ability to resist, absorb, recover from or successfully adapt to adversity or a change in conditions" (UNDRO, 1980).

Designing the flood risk management plan, the political authorities should improve and facilitate people participation, at several degrees, from empowerment, to ownership, to consultation, to simple information, improving the awareness of people in endangered areas (WMO, 2006). 
The results of flood risk management should be monitored by authorities, in order to better calibrate the planned interventions. Collected data should improve the informative systems and databases, increasing the total number of recordings of past events (Bovo et a. 2007). Monitoring should also include the after flood debriefing, in order to indicate to managers the lesson learned, and suggest what enhancements should be implemented. In this frame flood protection plans result to be an ongoing process, as they change in time, enhancing the territorial understanding of the flood risks and allowing a constant adaptation to changing circumstances and changing societal requirements. A good example of Italian experience in the mitigation-preparadness-recovery cyclic process can be found in Bovo et al. 2007, as far as Regione Piemonte (Italy) is concerned.

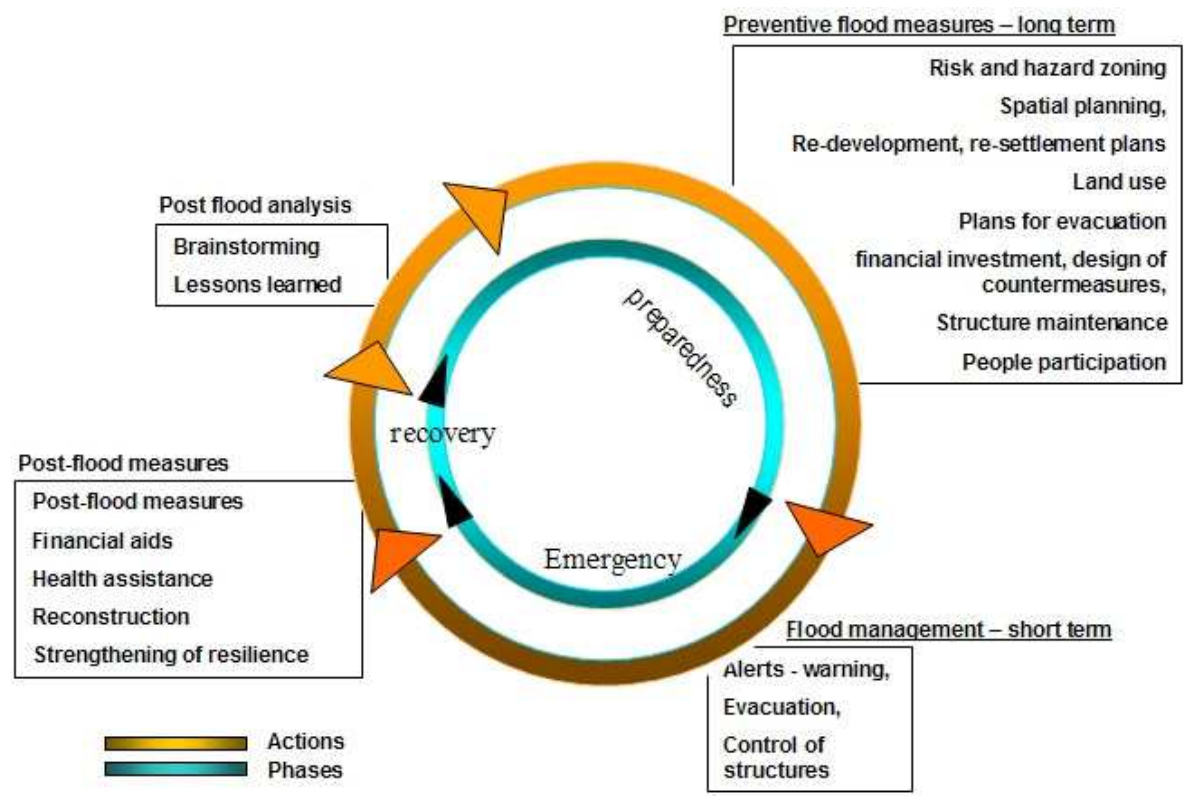

Fig. 7. Cyclic process in flood risk management.

From what has been above discussed, a discussion of the effectiveness of planning is necessary to understand what are the best ways to ameliorate the approaches described herein.

By referring to the FRM plan developed by the Po Basin District Authority (indicated with PAI), in the next section, the effectiveness of the FRM strategies is discussed, by referring to either to floods in main rivers or to flash floods in torrents. In particular the role played by the uncertainties in the risk assessment are discussed and put into evidence.

It will be put into evidence that the scenario-based planning is preferable when the uncertainties in risk assessment are less. The preparedness strategy has to be preferable for highly uncertain conditions, like in the case of alluvial fan flooding.

In the next section, the practices followed by the PBDA are described and discussed, as far as the main rivers in the Po basin are concerned. In particular, the effectiveness of the plan during a recent flood occurred in Northern Italy, in the Dora Baltea watershed is discussed. 


\subsection{Effectiveness of flood risk management in rivers (Po basin district)}

As anticipated in Section 2, different FRM strategies have been applied, in the course of the centuries, in the Northern part of Italy. The changes in strategies were either due to the political changes in the Governments, or to the evidence of the ineffectiveness of the practices that were followed till that time. It can be fairly stated that since 1989, the Italian legislation imposed a more advanced approach in FRM, well before the approval of the 2007/60 directive. Nevertheless the experience shows that risk management is an ongoing process, so that FRM plans have to be continuously adapted to new circumstances or physical evidences.

Therefore, in the following, the practices followed after the approval of the 183/89 act are described and their effectiveness is discussed, by referring to the 2000 flood in Dora Baltea river.

\subsubsection{The practices in risk assessment, evaluation and treatment}

Large inundations in Po watershed basin, either along the Po River or along its tributaries, are generally connected to extended rainfalls, generally linked to large meteorological perturbations. The soil moisture conditions play one of the major roles in the rainfallsrunoffs transformation, together with the rainfalls intensities, their geographical distributions, and, in some cases, the snowmelt. For instance the 2000 (October $13^{\text {rd }}-16^{\text {th }}$ ) flood would have been probably more severe if the drop in temperature did not transform the rainfalls precipitations into snow (Ratto et al., 2003), when the thermometric zero dropped from about $2800 \mathrm{~m}$ a.s.l. to about $1500 \mathrm{~m}$ a.s.l., in alpine regions.

From a methodological point of view, the amount of available data on floods occurred in the past, either quantitative or qualitative, shows a strong heterogeneity over the basin, so that the estimation of the hazard requires the application of hydrological and hydraulic models, probabilistic or deterministic. Historical data on floods are available either in a structured (like in hydrological annals, which were published by the hydrographic Italian service, up o the nineties, or in databases and informative systems organized by regional authorities (Bovo et a. 2007, Regione Piemonte, 2012)) or in a non structured (newspapers, witnesses, reports) way. Probabilistic estimation of floods is a very important step because, for the aims of PAI, flood risk assessment in Po basin refers to a protection level that is defined by the project flood discharge, estimated by means of the methods proposed in literature, which can be classified as direct or indirect methods.

Direct methods have been applied when the total number of locally recorded flood discharges allows a statistical inference of data. When data are scarce, or when the total amount of data did not allow a reliable statistical inference, indirect methods have been applied to estimate the flood discharges or the flood water levels, for the considered cross sections. Generally the complexity of the indirect methods spreads from the most empirical to the most detailed.

Determination of the project discharge for main rivers is in charge of the Po basin districts authority. The procedure, which was adopted in PAI and published in 1998 (PBDA, 1998), allowed the estimation of the design discharge for the most significant cross sections of the whole basin, by means of: 
- the regression analysis of the recordings in the annals;

- the estimation of the peak flood discharges which were not measured but that caused inundations; as far as Regione Piemonte (Italy) is concerned, an efficient and updated informative system for risk prevention, (named Banca Dati Geologica) includes hundreds descriptions of the effects of past inundations (Regione Piemonte, 2012), covering a period that extends from the 17 th century to now.

- the collections of the estimates of the peak discharges in papers, reports etc..

In this activity, a collaboration with the Regional Authorities, Research National Council and Universities demonstrated to be important to achieve a better interpretation of the available data and a better understanding of the possible magnitude of floods.

In the design discharge determination, the central concept is the flood return period, also known as recurrent interval.

The theoretical return period is the inverse of the probability that the event will be exceeded in one year. For example, a 10 -year flood has a 1 / $10=0.1$ or $10 \%$ chance of being exceeded in any one year and a 50 -year flood has a 0.02 or $2 \%$ chance of being exceeded in any one year. Correspondently, if a discharge $Q$ has the return time $T$, it means that it can be exceeded, on average, once in $\mathrm{T}$ years.

For the main rivers, the hazard assessment in the Po watershed basin has been made by referring to different return periods $T$, that is $T=200$ years and $T=500$ years, and therefore two different design discharges, which are respectively $Q_{200}$ and $Q_{500}$, have been estimated for a set of relevant river cross sections.

The estimations of the design discharges have been published by the District authority and are available for the public, together with the estimations of the water levels for different return periods (PBDA, 1998).

By applying hydraulic and geomorphologic models, the PBDA proposed a classification of hazards that is mainly based on the concept of the river corridors (table 6, fig.8), which are indicated as corridors A, B and C. The corridors are defined by considering two complementary components, that are the hydraulic component and the geomorphologic component. As far as the hydraulic component is concerned, the corridors are defined as follows:

- B corridor: it corresponds to the areas which can be flooded by a design discharge of 200 years, $Q_{200}$, with velocities less than $0.4 \mathrm{~m} / \mathrm{s}$;

- A corridor: it corresponds to the areas where al least the $80 \%$ of the total design discharge $\mathrm{Q}_{200}$ flows;

- C corridor: it corresponds to the areas which can be flooded by a design discharge of 500 years, $Q_{500}$

These corridors have been mapped on 1:25.000 scale, all over the Po watershed basin. (PBDA, 2001).

When the actual defence system is not sufficient to avoid the flooding of the $\mathrm{Q}_{200}$ discharge in areas that should be protected, the designed limit of inundation is represented on maps by means of a different graphic item, that is called "B design limit". This limit indicates that the present protection system shows a deficit and that appropriate countermeasures to avoid the flooding of $\mathrm{Q}_{200}$ discharge should be implemented, such as new levees or embankments. As long as the risk situation remains unchanged, stricter soil use regulation 
are in force in the areas behind the B design limit. The approach of fluvial corridor has been followed also elsewhere (OPW, 2008).

\begin{tabular}{lll} 
& Hydraulic component & Geomorphologic component \\
\cline { 2 - 3 } B corridor & $\begin{array}{l}\text { Areas flooded by the design } \\
\text { discharge having T=200 years, } \\
\text { with velocities less than } 0.4\end{array}$ & $\begin{array}{l}\text { Reactivation of recently } \\
\text { abandoned watercourses } \\
\mathrm{m} / \mathrm{s}\end{array}$ \\
\hline A corridor & $\begin{array}{l}\text { Areas where al least the } 80 \% \text { of } \\
\text { the total design discharge } \mathrm{Q}_{200} \\
\text { flows }\end{array}$ & $\begin{array}{l}\text { Reactivation of recently } \\
\text { abandoned watercourses }\end{array}$ \\
\hline C corridor & $\begin{array}{l}\text { Areas flooded by the design } \\
\text { discharge having T=500 years }\end{array}$ & $\begin{array}{l}\text { Reactivation of abandoned } \\
\text { watercourses }\end{array}$ \\
\hline B design limit & $\begin{array}{l}\text { The actual defence system does } \\
\text { not avoid the flooding of the }\end{array}$ & \\
& $\begin{array}{l}\text { 200 years design discharge } \\
\text { beyond the limit. Protection }\end{array}$ & \\
& works are necessary to protect & \\
the 200y-flood prone areas. & \\
\hline
\end{tabular}

Table 6. Technical definition of the fluvial corridors approach.

Risk vulnerability and exposure components are estimated by means of qualitative scales (Table 3). Risk classes are ranked by intersecting the different exposure/vulnerability classes with hazards, obtaining four risk classes. At the present implementation state of PAI, risks are not mapped on topographic layers but refer to administration units. In other words, for each municipality, a risk class has been assigned, without mapping the risks on floodplains. As to the receptors at risk, they are indirectly pointed out in the implementation norms (PBDA, 2001b), which refer to the most relevant categories of receptors which are inside each flooding corridor, discriminating the actions needed, the regulation of activities, prescriptions and prohibitions (Table 7).

\begin{tabular}{llll} 
Existing structures & \multicolumn{3}{c}{ New structures } \\
\hline Allowed & Not allowed & Allowed & Not allowed \\
\hline Ordinary manutention & Enlarge cubage. & Public works, & Drinkable \\
work, with & Enlarge total & bridges. & treatment implants. \\
implementation of & occupied area. & & Garbage treatment. \\
vulnerability mitigation & & & Campings. \\
devices. & & & New settlements.
\end{tabular}

Demolition without

reconstruction.

Table 7. Example of regulations in A corridor. The table is a simplification of the art. 29 of the implementation norms (PBDA, 2001b).

One of the limitation of the followed approach is that the hazard is defined by referring to the inundation of the design discharges, without considering that locally the real hazard conditions can be very different. For example, some urbanized areas are in the same 
corridor but can experience different water levels during the same flood, or can be affected by floods with a different frequency.

As far as this procedure is concerned, it is remarkable that the reference to return periods does not consider river geographic location, so that the approach it is uniform all over the river basin. Some local exceptions can be found for rivers where the $\mathrm{Q}_{100}$ design discharge has been adopted, instead of the $\mathrm{Q}_{200}$.

As indicated before, the implementation norms represent an important legal component to detect receptors at risk and to treat risk in PAI, and are complementary to the following other actions in PAI for risk treatment, which are:

- the implementation of a program of interventions, founded by the national government; standard designs of the typical structural countermeasures are provided (PBDA, 2001c);

- involvement of local administrations, which have to adapt local planning to hazards zonation and implementation norms; the general strategy is to avoid to increase the total risks on flood prone areas, reducing the total exposure or the vulnerability;

- $\quad$ risk transfer, which does not refer to insurance obligations, but it is related to a physical transfer of flood risks; as mentioned before, in Po basin, the floods effects in the valley part (namely the areas next to the Po delta) strongly depend on the lamination processes that take place in upper part of the watercourse, either spontaneous (flooding in alluvional areas) or man-induced (retention ponds); therefore large flooding areas for peak flood lamination are designed and maintained, in order to make the floods less severe for downstream areas; in this frame, flood risk is retained in the upper part of the basin.

The PAI allows an efficient participatory approach for hazard mapping and risk management. Participation of local administrations, stakeholders and people was already allowed in the implementation phase of PAI, so that private and public remarks could be submitted to and discussed with PBDA to modify, change or adapt the PAI to local situations. As an ongoing process, after the adoption in 2001, some local revisions to PAI have been proposed and adopted by the PBDA, in order to enlarge the risk management approach of "river corridors" to more rivers. When recent floods showed that the risk management had to be revised, the PAI has been updated accordingly. This is the case of 2000 flood, which occurred in the North Western part of Italy and showed to be an exceptional event, from a statistical point of view. At present, the approaches followed in PAI are being integrated and completed according to the requirements of the 2007/60 European directive.

\subsubsection{Discussion on the effectiveness of FRM - The 2000 flood in Dora Baltea river}

In decision making about flood risks, it should be considered that risk assessment is generally based on estimations, which are affected by several uncertainties and can show to be inaccurate if compared to real flood effects. Comparison among depicted scenarios and reality is a useful tool to learn useful lessons about scientific and management limitations (Table 8), as it can be deduced by the study case of the 2000 flood in Italy.

On October 13-16th, 2000 heavy rainfalls interested the North-western Italian Alps from the upstream reach of the Po river to the Ticino river, causing huge flooding and landslides with significant damages to houses and infrastructures and several life losses (Ratto et al., 2003). 
The whole Valle d'Aosta region (excluding the North-Western sector where less damages have occurred) was interested by extensive flooding, landslides, soil slips and debris/earth flows on the alluvial fans with damages to houses and infrastructures for more than 500 million euro and several life losses in the population (14 persons died). From a hydrological point of view, the discharges data (recorded or reconstructed) showed to be exceptional, as they were higher than those previously recorded in annals since 1925 by the hydrographic Italian service. In Piemonte the areas near Ivrea were seriously affected by the flood, an abandoned course of the Dora Baltea (named Rio Ribes) was reactivated and discharges by far higher than the estimated ones were convoyed downstream. Several bridges broke down and the road connections were interrupted for many hours.

On October 18-19th the areas involved by the event were surveyed through aerial photography. The survey was focused also on the Dora Baltea river (watershed basin area: $3920 \mathrm{~km} 2$ )valley line, on the adjoining mountainsides, and on the valley lines of the main tributaries. Dora Baltea is a tributary of the Po river, and therefore is under the administrative competence of the PBDA.

The surveys were carried out through the following steps:

- through aerial photography interpretation techniques a thematic cartography in scale of 1 : 5000 and 1 : 10000 has been produced, highlighting the main typologies of hydrogeological phenomena identified;

- the produced thematic cartography has been digitized and georeferenced in order to allow an integrated use with information of different type and provenance;

- the thematic cartography has been updated and corrected as a result of numerous direct surveys.

Since a risk assessment plan was already in force since 1998 all over the Po basin (named PSFF - plan of fluvial corridors, adopted by PBDA; PBDA, 1998), the effects of the 2000 flood allowed the district authority to check the effectiveness of the risk assessment procedures which had been adopted.

In particular (Table 8), as far as flooding in Dora Baltea is concerned, the comparison of risk assessment and reality showed the situations where the system of fluvial corridors demonstrated to be effective, and the areas where it had to be revised. Nevertheless the philosophy of the fluvial corridors systems was maintained and integrated.

A hydrological and a hydraulic model were applied to revise the risk analyses previously made (Table 8). The major discrepancies in risk assessment were due to the underestimation of the design discharges in the old PSFF plan. Thanks to a more detailed topographic support available for technicians a more precise analysis of the inundation areas was carried out.

Indications on the acceptable risk levels for different kinds of receptors in corridors have been given, in order to guide the municipalities to a major awareness in planning. This was a step towards a more detailed management of risks in floodplains, and a substantial improvement of the approach that was followed in PAI. In particular, for the receptors on floodplains, it has been performed an analysis of the actual protection level, which has been classified into deficit (when the actual protection level is less than that acceptable) and surplus, and ranked (Figure 9). 
Moreover it was planned to apply and calibrate, on the whole Dora Baltea river basin, numerical models for the rainfall-runoff and flood propagation simulation, in order to forecast critical events along the hydrographical network starting from the forecast and observed data. This improves the data management during the events through the consecutive issue of bulletins to the civil protection offices, updating the measured data and their trend, allowing the decision-making processes based on the more probable scenario (Ratto et al. 2003). However, it has been observed that the alert system, organized by Regione Piemonte Authority, and people preparedness hugely contributed to reduce the total number of victims. Dissemination of information of hazard alerts proved to important for a timely decision making.

After analysing the discrepancy between risk floods scenarios made before the flood and real flood effects, it should be noted that the reasons for such discrepancy have to be substantially found in the uncertainties which affected technical evaluations in the 1998 plan.

\begin{tabular}{|c|c|c|}
\hline & What has been observed & What has been done \\
\hline $\begin{array}{l}\text { Risk assessment } \\
\text { hydrological } \\
\text { hazard }\end{array}$ & $\begin{array}{l}\text { Discharges (measured at } \\
\text { gauges stations or estimated } \\
\text { by means of back analysis) } \\
\text { during the flood revealed to } \\
\text { be outliers. } \\
\text { The flood peaks data, } \\
\text { available at the date of the } \\
\text { flood, had to be integrated. }\end{array}$ & $\begin{array}{l}\text { Revision of hydrology } \\
\text { Revision of the design discharge } \\
\text { adopted by PBDA; the highest } \\
\text { increment of the design discharge are } \\
\text { about } 20 \% \text { (Tavagnasco cross section). }\end{array}$ \\
\hline Risk assessment & $\begin{array}{c}\text { Flooding areas resulted to be } \\
\text { outside the hazard areas (see } \\
\text { Figure 8). } \\
\text { Geomorphological processes } \\
\text { showed to have been } \\
\text { underestimated. }\end{array}$ & $\begin{array}{l}\text { Corridors } \mathrm{A}, \mathrm{B} \text {, and } \mathrm{C} \text { have been } \\
\text { revised (Figure } 8 \text { ) and the new PAI } \\
\text { version was adopted again by PBDA, } \\
\text { after discussion with regions, } \\
\text { stakeholders, municipalities, people. }\end{array}$ \\
\hline Risk evaluation & $\begin{array}{l}\text { Some anthropic activities are } \\
\text { inconsistent with respect to } \\
\text { the risk assessment. }\end{array}$ & $\begin{array}{l}\text { PBDA adopted a list of activities which } \\
\text { are considered to be acceptable or not } \\
\text { acceptable, depending on the risk level. }\end{array}$ \\
\hline Risk treatment & $\begin{array}{l}\text { The actual structural defence } \\
\text { system revealed not to be } \\
\text { effective }\end{array}$ & $\begin{array}{c}\text { Risks and hazard maps have been } \\
\text { updated, and non structural } \\
\text { countermeasures have been } \\
\text { implemented } \\
\text { Surplus and deficit in the protection } \\
\text { levels have been mapped on local scale } \\
\text { (figure 9). } \\
\text { Programming structural and non } \\
\text { structural interventions (total about } \\
100 \mathrm{M} € \text { ) } \\
\text { Reconstruction of damaged } \\
\text { infrastructures }\end{array}$ \\
\hline
\end{tabular}

Table 8. Post flood analysis after 2000 flood event in Dora Baltea. 


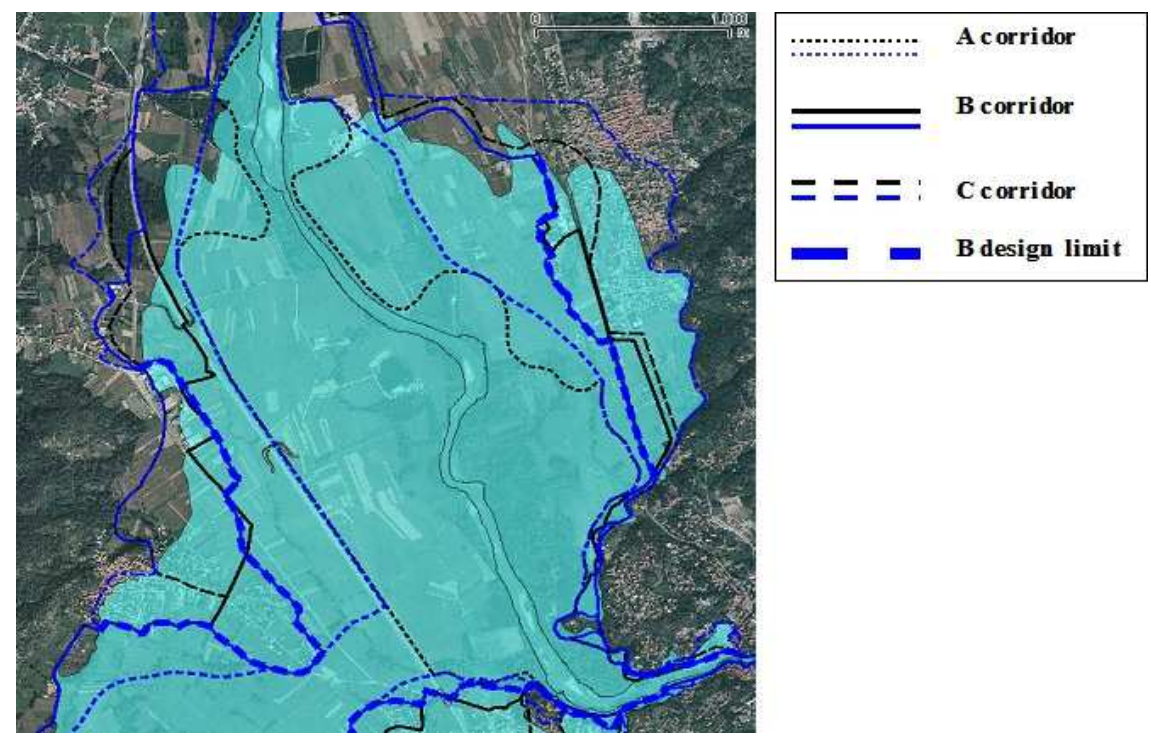

Fig. 8. Flooded areas near Ivrea, with the superposition of the fluvial corridors (before the event, black colour) and after revision of the PAI (in blue colour).

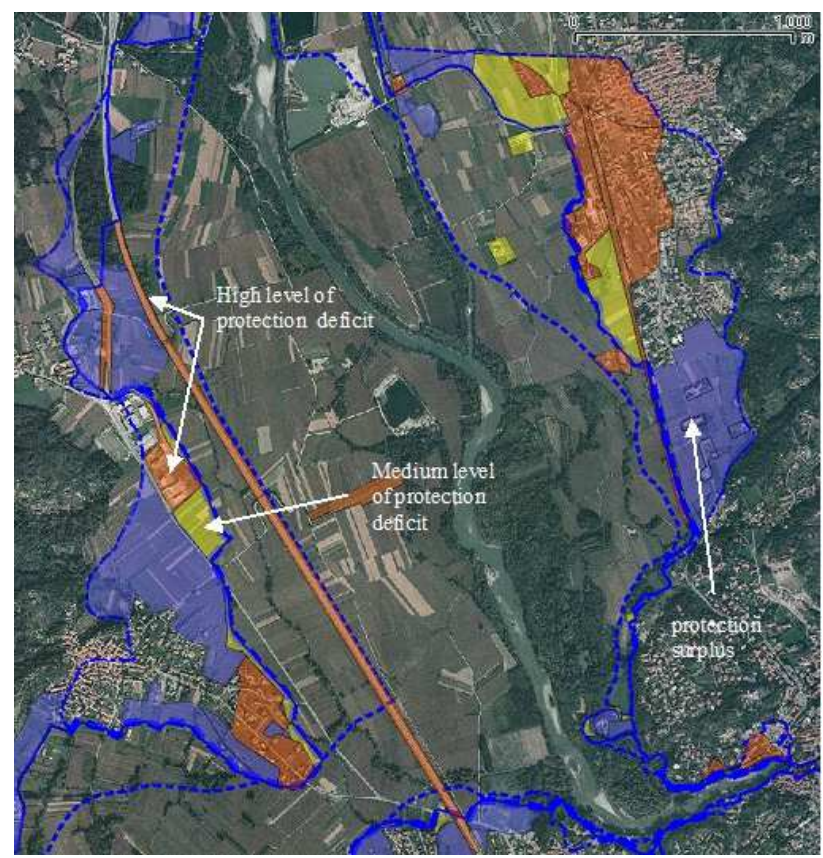

Fig. 9. Zoning of the areas near Ivrea (PBDA, 2008). Each colour corresponds to a different protection level. In yellow and orange areas there is a deficit in the protection level; in blue areas there is a surplus. 
The 2000 flood put into evidence two different categories of uncertainty in technical assessments, which can be described as knowledge uncertainty and structural uncertainty (Floodsite, 2009).

As to the first source of uncertainty, after 2000 flood, the estimated peak discharge datum (reconstructed by means of a hydrological and hydraulic back analyses) resulted to be higher than the maximum historical recorded value, so that the hydrological assessment made before the flood event resulted to underestimated. Such a discrepancy between assessments and reality is typical when new data are available (Gribbs, 1969). The evidence of a new datum (the 2000 flood peak) improved the basic knowledge of the hydrological regime of Dora Baltea river, described by a set of data available in more than 70 years of observations (Claps, 2008). This induced the PBDA to revise past hydrological assessment and to consider more sever design discharge floods.

As to structural uncertainty, the geomorphologic dynamics of Dora Baltea river during the flood showed the necessity to improve the modelling of flooding. In particular the reactivation processes in Rio Ribes had to be modelled with a higher accuracy, and a higher detail. Actually, in 2000 flood the reactivation of the secondary river, Rio Ribes, near Ivrea occurred in a way that was not completely predicted, although reactivation processes were already taken into account in the PSFF plan adopted in 1998 (PBDA 1998), on the base of the reactivation which already occurred in in 1920, 1993 and 1775, 1834. Actually the overtopping of the 2000 flows occurred in two cross sections where, during the 1993 recent flood event, no flooding was experienced (Turin Province, 2006). A highway and a national road were seriously damaged, and urbanized areas were heavily flooded. The magnitude of reactivation has been a subject of analysis, resulting that the design discharges in Dora Baltea upstream the Rio Ribes is about $2800 \mathrm{~m}^{3} / \mathrm{s}$ and that about the $40 \%$ of the total discharge flows in the secondary river.

In order to control the reactivation processes, a large weir has been design in the areas where the fluvial reactivation takes place, substantially controlling the way in which the discharges enter the Rio Ribes, and controlling therefore the total discharges that flow downstream.

The risk management plan in Dora Baltea is now in force since the 2008 (Deliberation of the institutional committee, n.4/2008; PBDA, 2008).

\subsection{Effectiveness of flood risk management in torrents (Regione Piemonte, Po basin district)}

From a normative point of view, following the indications given by the PBDA in the PAI plan, FRM approaches can vary from region to region, especially as far as the hazard and risk assessment methodologies are concerned.

Therefore, in the following, the practices followed in Piemonte region (Deliberation n. 211830) are described and their effectiveness is discussed, by referring to a 2008 flash flood in Pellice catchment.

Note that from a geographical point of view, it should be mentioned that Piemonte region is at the head of the Po river catchment and it is prevalently mountainous. Actually about $43 \%$ of the total territory lays in the Alps, or in Apennines, and abut $30 \%$ is hilly. As a 
consequence, due to the total number of torrents and the relatively small dimensions of the catchments, the assessment of the flood risks has to be very detailed.

\subsubsection{The practices in risk assessment, evaluation and treatment}

As far as torrents are concerned, in principle, flood hazards can be assessed by means of the methodology previously described, but it should be clear that the related phenomena can be very different in reality.

What is more challenging is that, in Alpine catchments, different kinds of currents can alternate in time in the same torrent (and its fan), from those which are more related to landslide liquefactions, to debris flows, to immature debris flows (Takahashi 1991) to ordinary water currents. Experience in some instrumented basin (e.g. rio Moscardo, Italy) show that the flood processes in alpine torrents can have mechanics that are intermediate between those of water flows (showing a Newtonian rheology) to those of debris flows. Back analysis confirms this behaviour also from a phenomenological point of view, even if it is very difficult to understand the inner nature of the process, as both phenomena are impulsive, the onset is very fast and the transported sediment carried by the flow is not negligible (Arattano and Franzi, 2004, 2006). Moreover, during the same event, different processes can alternate in time or superpose. Some of the most critical situations are represented by floods on alluvial fan, which are due to the spreading of the currents on debris cone.

As far floods on alluvial fan are considered, the frequency of occurrence is widely debated in literature, as the flood intensities are strongly dependent on the sediment and debris transported by the flow. Therefore the statistical quantification of the severity of the process is generally very problematic. Also the recourse to modelling is very problematic, as the mechanical behaviour of the flood currents cannot be determined a priori and the rheology is in general non Newtonian. Consequently hazard mapping on alluvial fans necessarily considers different scenarios, the frequency of which is generally only roughly estimated. To this aim the historical data can help the decision makers to propose solutions for the endangered areas (PBDA, 2001a).

Simplification and classification is needed and regulation in planning generally helps the practitioners. As far as torrents, the PBDA classifies two different processes that are equally related to meteorological causes:

- the flooding processes along the torrents with or without the deposition or erosion of sediments; these are indicated as linear processes, since they take place along a watercourse; according to PAI implementation guidelines in Regione Piemonte (act $\mathrm{n}$. 2-11830, 2009), flood risk assessment relies on the concept of the return period (Table 9);

- the flooding on alluvial fan, due to the water sediment flows entering the alluvial cone, with or without the deposition of sediments; these are addressed to fan processes; since the reference to a statistical flooding recurrence is not attainable (and the estimations of the recurrence periods are no more realistic) the PAI risk assessment in made by referring to "fan reactivation" concept (Table 9). This concept matches quite well with the definition given by FEMA (2007) about alluvial fan flooding: "Flooding occurring on the surface of an alluvial fan or similar landform which originates at the apex and is characterized by high-velocity flows; active processes of erosion, sediment transport, and deposition; and unpredictable flowpaths" (FEMA, 2007). 
Torrent floods

Very high hazard corridor - Ee corridor:

Alluvial fan flooding

areas flooded by a design discharge

having a return period between $\mathrm{T}=20$ -

50 years

High hazard corridor - Eb corridor: it is

outside the Ee corridor; areas flooded by

a design discharge having a return

period between $\mathrm{T}=100-200$ years;

Very high hazard $(\mathrm{Ca})$ : alluvial fans where torrents showed water-sediment flooding, with sediments deposition, in the last 30 years; the fan areas are not presently protected.

High hazard $(C p)$ : alluvial fans where torrents showed water-sediment floodings, with sediments deposition, in the last 30 years; the fan areas can be protected, but the works are not still sufficient to maintain an acceptable level of risk.

Medium-moderate hazard corridor - Em corridor: outside the Eb corridor; areas flooded by the design discharge having a return period between $\mathrm{T}=200-500$ years;

Mean or moderate hazard $(\mathrm{Cn})$ : alluvial fan where torrents did not showed any flooding process in the last 30 year or where flooding areas in the fan are protected (protection works along the torrent or located on the alluvial fan)

Table 9. Criteria for hazard zoning in Piemonte region, following the indications given in PAI (PAI, Relazione Generale, p.213). The criteria have been modified by the regional deliberation DGR2-11830, published on the official regional bulletin (Note: the indication in the table is an oversimplification of the deliberation, which consists on tens of pages).

Obviously the two kinds of processes are strongly connected, since the only distinction between the two is the topographic location (along a torrent or o the torrent fan) but there is a physical continuity in the water-sediment discharges that run torrents, deposit on debris fans, and flow downstream, connecting, as tributaries, to other rivers or torrents.

In this frame, the risk assessment in alluvial fan flooding is affected by higher uncertainties, mainly due to the fact that the estimation of the recurrence period of such processes remains unknown. It is generally false that the recurrence of the alluvial fan flooding processes is the same as that of hydrological triggering conditions, even when mathematical formulations of hydrological thresholds are proposed in literature. Moreover the intensity of the processes can strongly vary from one event to another, so that the total volume of deposited sediments or the morphological changes or the channel cutting on the fan, can strongly change according to the "boundary" conditions which are unknown.

For this reasons, the strategy that is generally followed, is based on civil protection measures.

What is more challenging for civil protection agencies is what should be done in real time, in critical hydrological conditions. Actually considering the total number of fans that are potentially endangered (in Piemonte the total number of alluvial fans is about 2400, Arattano et al. 2010), risks cannot be generally managed by adopting generalized civil protection countermeasures (i.e. by ordering evacuations, which would result in false alarms) in real time conditions; the strong spatial variability of rainfall intensities and the strong uncertainties in threshold rainfall conditions cause the decision making to be very uncertain too. 
For instance, 24 hours before the fan flooding in Villar Pellice in 2008 (Figure 10), the regional environmental agency, by applying some meteorological models, established that in the Pellice valley the risk level, for the next 36 hours, was rated "3" ("high criticality" level) in a scale that ranges from 1 to 3 . This level corresponds to the possible occurrence of "soil slips, debris flows and floodings".

However the bulletin was based on a rainfall forecasting at a regional scale and it could not give more precise indications on the exact location where the highest rainfall intensities might have occurred. Therefore the issue of the determination of the possible receptors at risk was just "downscaled" from a total 2400 fan areas, to about 100 fan areas of the Pellice river basin $\left(293 \mathrm{~km}^{2}\right)$. What is more impressive is that some hours before the event, there were no rainfall evidences about a possible flooding on Villar Pellice. Risk assessment in real time conditions showed to have strong limitations.

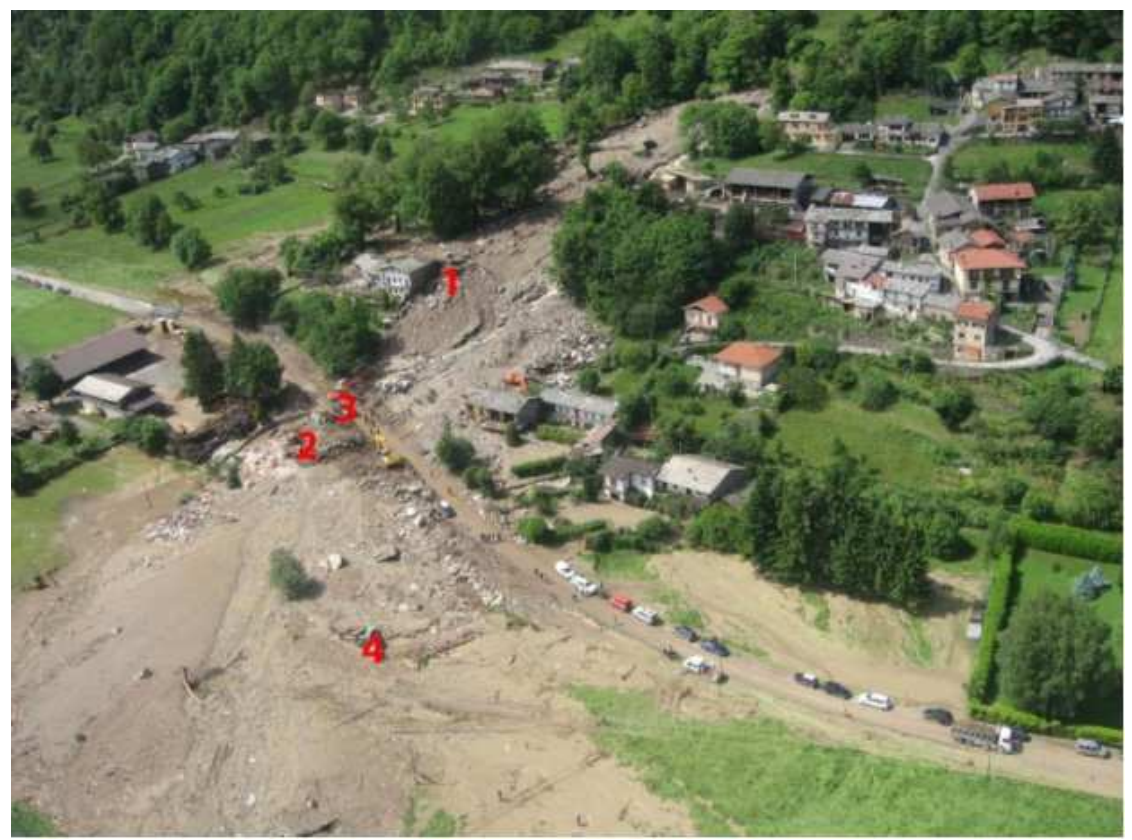

Fig. 10. Aerial view of Garin, affected by the debris flow of Cassarot creek occurred on 29 May 2008. 1 - destroyed house; 2 - more destroyed building; 3 - location where one of the cars hit by the flow was found (the fourth victim); and 4 - location where the ambulance and the tractor, hit by the flow, were found.

Uncertainties effect risk assessment, risk evaluation and also risk treatment. Decision making on the priority of interventions ("if" and "which" alluvial fans should be sheltered) on a total of 2400 fan areas is therefore a very hard task, that lead local administration to ask for higher economical budgets, in order to have the chance to treat the highest possible number of situations. Consequently the implementation norms (PAI, 2001b) are more restrictive as far as the activities are concerned. In Table 10 an example regarding the Eb corridor and the Ca zones is provided. 


\begin{tabular}{|c|c|c|c|c|}
\hline & \multicolumn{2}{|c|}{ Existing structures } & \multicolumn{2}{|c|}{ New structures } \\
\hline & Allowed & Not allowed & Allowed & $\begin{array}{c}\text { Not } \\
\text { allowed }\end{array}$ \\
\hline $\begin{array}{l}\mathrm{Eb} \\
\text { corridor }\end{array}$ & $\begin{array}{l}\text { Enlargement for sanitary } \\
\text { and functional adaptations. } \\
\text { Manutentions. Renovations, } \\
\text { without enlargement in area } \\
\text { and cubage }\end{array}$ & $\begin{array}{l}\text { Enlarging cubage. } \\
\text { Enlarging total } \\
\text { occupied area. }\end{array}$ & $\begin{array}{l}\text { Drinkable } \\
\text { treatment } \\
\text { implants }\end{array}$ & $\begin{array}{l}\text { New } \\
\text { settlements. }\end{array}$ \\
\hline $\mathrm{Ca}$ & $\begin{array}{l}\text { Demolition without } \\
\text { reconstruction. } \\
\text { Ordinary and extraordinary } \\
\text { maintenance work. } \\
\text { Vulnerability mitigation } \\
\text { devices. }\end{array}$ & $\begin{array}{l}\text { Enlarging cubage. } \\
\text { Enlarging total } \\
\text { occupied area. } \\
\text { Agricultural changes } \\
\text { in cultivation types. }\end{array}$ & $\begin{array}{l}\text { Defence works. } \\
\text { Enlargement of } \\
\text { implants for } \\
\text { sever water } \\
\text { treatment. }\end{array}$ & $\begin{array}{l}\text { New } \\
\text { settlements. }\end{array}$ \\
\hline
\end{tabular}

Table 10. Example of regulation norms in Eb corridor and in the Ca alluvial fan. The table is a simplification of the art.9 of the PAI implementation norms (PAI, implementation norms, 2001).

\subsubsection{Discussion on the effectiveness of FRM - The $\mathbf{2 0 0 8}$ fan flooding in Villar Pellice}

The 2008 event occurred in Villar Pellice can be considered representative of the many high uncertainties which practitioners and decision makers have to deal with, when the alluvial fan risk assessment is considered.

Indeterminacy of the flood occurrence was mainly due to the fact that the processes, that is the spreading of water and sediment on the alluvial fan, could not (or only partly could) be determined from the data available, i.e. real-time rainfalls and historical background.

During the May 28-30 2008 meteorological event, many soil slips originated in the Pellice valley, generally triggered above $1500 \mathrm{~m}$ a.s.l.. The alluvial fan flooding in Villar Pellice hit the inhabited areas at 10.25 a.m. and was preceded by the activation of a series of soil slips that interrupted in different points the viability, making the area inaccessible. The deposits left by the flow that run the Cassarot creek covered an area of about $28,000 \mathrm{~m}^{2}$, with a maximum thickness up to $3 \mathrm{~m}$. The estimated total transported volume was about $40,000 \mathrm{~m}^{3}$ (Lollino et al., 2008).

The May 29, 2008 disaster caused tragic effects: four casualties, 24 four buildings and three cars (among which an ambulance) hit by the debris flow (Figure 10). Four people died, three in the house destroyed by the current and another in a car (number 3 in Figure 10). Another house was also destroyed (number 2 in Figure 10) without losses.

As witnessed by the Villar Pellice inhabitants, the current consisted probably of a single debris flow wave that was preceded by a loud noise. The witnesses were not aware of what was going on, even if the water discharge of the Cassarot creek had already flooded the street. A technician of the municipality carried out a survey about 40 minutes before the event. According to this survey, the Cassarot creek already showed a very high discharge that was however contained within the channel, there were no flood evidences and the road crossings were all practicable. Before the debris flow arrival, there were no evident signs of 
the imminence of the event. Rainfalls intensities in the hours before the flooding showed a strong spatial variability but anyhow they cannot considered as exceptional. At Bobbio Pellice rain-gauge station (the nearest to the flooding area) the rainfalls intensities maintained for several hours less than $10 \mathrm{~mm} / \mathrm{h}$ (an intensity which is not exceptional for alpine areas), and increased suddenly from about $12 \mathrm{~mm} / \mathrm{h}$ to more than $45 \mathrm{~mm} / \mathrm{h}$, when probably the debris flood was triggered (Figure 11).

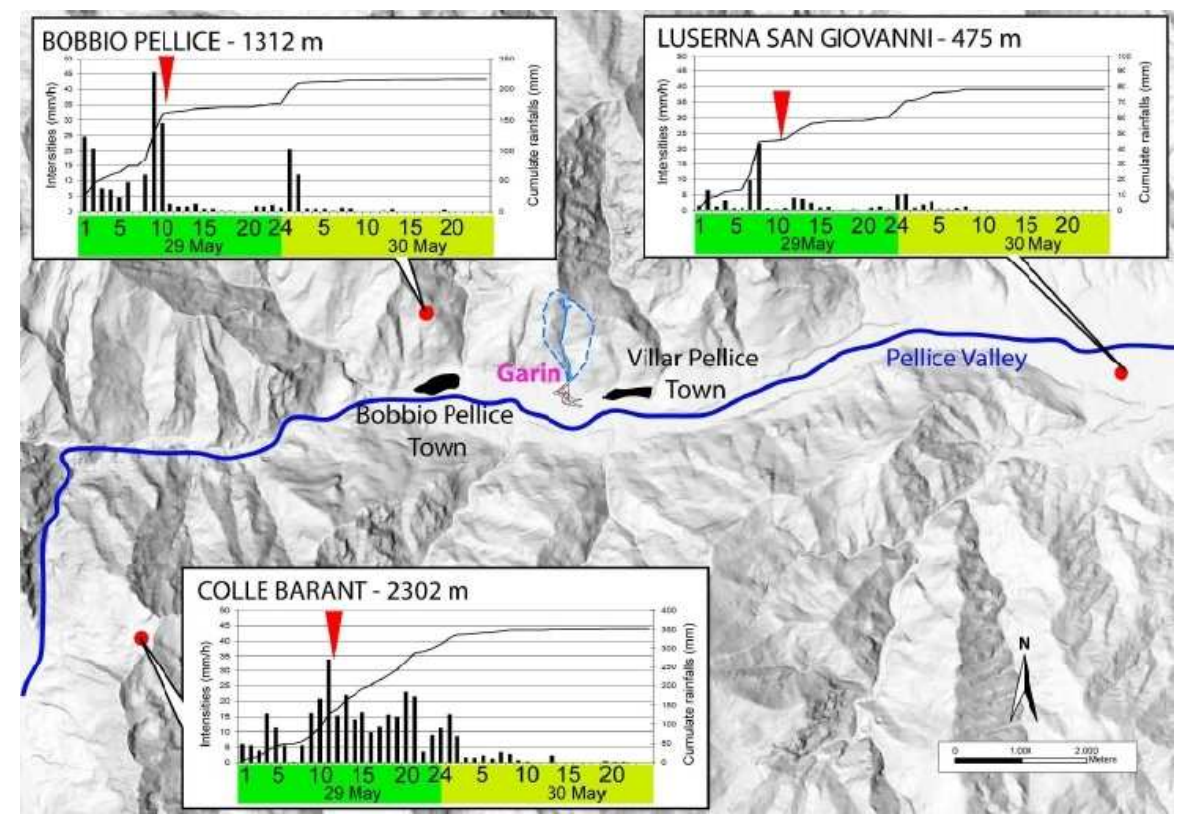

Fig. 11. Location of the raingauges near Villar Pellice with the intensities and cumulated rainfalls on 29-30 May 2009 (the start time for all of the graphs was midnight on 29 May). The red arrow shows the debris flow time occurrence.

From the viewpoint of territorial planning, the available data and the field surveys carried out on the Cassarot torrent, had allowed a hazard mapping on the fan at a local scale, as indicated in figure 12. The hazard areas mapped in Villar Pellice, which were proposed to the local administration but were not still in force, were partially confirmed by the 2008 event. In particular, one of the destroyed houses (house A in Figure 12) was in an area where the debris flow hazard was classified as "high" and "partially" protected (Cp areas, figure 12), while in the adjacent areas the hazard was classified as "medium" ( $\mathrm{Cn}$ areas). The other destroyed house (B in figure 12) was in an area where the flood hazard was classified as "very high" (Ee areas).

The comparison among the risk assessment and the reality allowed us to reconsider risk assessment on the fan.

As far as zone mapping on alluvial fan is considered, the zoning of high hazard matches quite well with the flooding areas. According to hazard maps, in Ee areas (which have been considered outside the possible fan flooding processes), the prevailing hazards were due to 
valley processes, that is the flooding of Pellice river which flows downstream the fan. Risk assessment and evaluation was probably biased by historical information about antecedent processes, a source of information that guide technical decision making in high uncertainties. Actually, the comparison of different images of the Garin alluvial fan (Figure 13), shows that, after the 1977 event, the processes affected a part of the fan without causing any damage to the house destroyed in 2008. In 1998 the image shows the house destroyed in 2008 as it was until the day before the 2008 event; the image presents a very different situation compared to the following and it is particularly important because it allows to evaluate which was the morphological context in which those who carried out an evaluation of the hazard of the area had to operate. The 2008 picture shows the post-event situation in all its drama.

The experience gained in the alluvial flooding allowed the regional authorities to make more steps towards real time assessment of hazards and risks. In particular it was observed (Table 11) that the assessment of the risks could be improved by increasing the risk perception of people living in endangered areas, and helping majors of small municipalities to take decisions in real time by experts (Booker et a., 2009). Moreover a collaboration among weather forecasting centres and experts is also necessary, so that the real time estimations of local rainfalls obtained by radars can allow to take decisions more rapidly and to improve the performance of civil protection strategies and protocols (Borga et al., 2006).

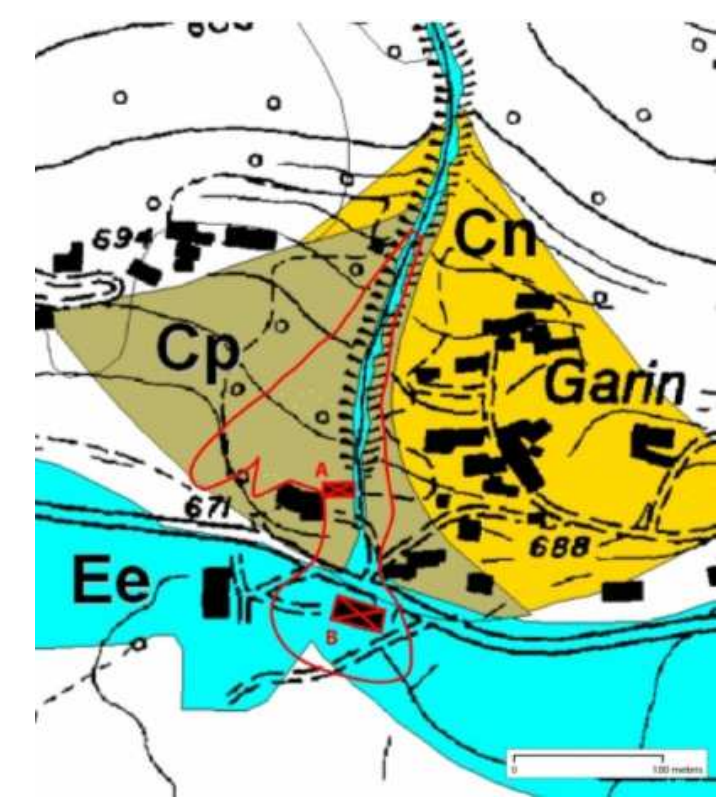

Fig. 12. Hazard mapping on the Villar Pellice fan. In this picture, the areas that are shown are classified by areas at risk: $\mathrm{CP}$ - area characterised by high debris flow hazard and partially protected; $\mathrm{C}$ - area characterised by medium debris flow hazard; Ee - area characterised by very high water flood hazard. The red line shows the limit of debris flow deposits. 


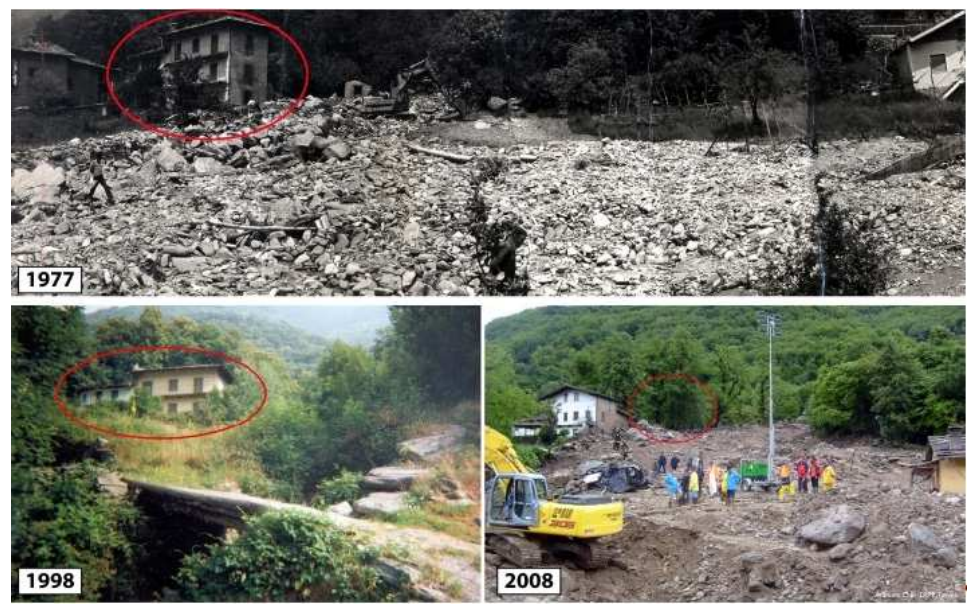

Fig. 13. Comparison of different images of the Garin alluvial fan: after the 1977 event - as the image shows, the debris flow affected a part of the fan without causing any damage to the house destroyed in 2008. In 1998 - the image shows the house destroyed in 2008 as it was until the day before the 2008 event.

What has been observed What has been done

Rainfall conditions showed a high spatial variability (in the range between $10 \mathrm{~mm} / \mathrm{h}$ to $45 \mathrm{~mm} / \mathrm{h}$. The processes showed high onset velocity and very high energy.

Rainfalls, some hours before the onset, Risk assessment could not be considered as exceptional.

There was no evidence, in real time conditions, about the onset of the process.

Flooding areas resulted to partially match with those mapped in the hazards maps;

The presence of houses resulted to be inconsistent with respect to the

Risk evaluation evidences of risk. The high onset velocity did not leave enough time for evacuation.

Threshold rainfall conditions for the process onset are going to be determined. Risk assessment has been revised locally; no return periods for this kind of events have been assessed.

A different hazard zoning has been proposed
Mitigation of risk by means of structural countermeasure is not probably effective.

Risk treatment The energy of the process on the fan area shows that the vulnerability of the houses cannot be properly reduced.
Risk evaluation was revised, locally. People living in areas where the risk is not tolerable, have been relocated.

Some houses are going to be relocated. More effective civil protection countermeasures are in study.

An improvement in spatial and temporal forecasting, action protocols, dissemination of hazard alerts and timely decision making is needed.

Real-time meteorological alerts through the analysis of radar images are in study.

Table 11. Post flood analysis after 2008 disaster in Villar Pellice. 


\section{Closure and future work}

Experience in risk management let decision makers to consider that floods are generally the result of complex interaction among different factors, mainly anthropogenic and natural, random and deterministic. Many factors are considered to be constant in time (assumption of stationarity) without considering any dynamic changes. If, on one hand, this is a first order approximation for the description of natural phenomena, on the other hand it should be clear that the watershed characteristics undergo continuous changes in time. Plans should be enough flexible to adapt to these changes.

Together with the uncertainties due to the non-stationarity of the factors, a reliable FRM strategy should also take into account the different sources of uncertainties, which can be very representative, as in the case of the Dora Baltea river or of the Cassarot torrent. It is therefore confirmed that risk planning is an on-going process that is an interim product based on information and understanding at the moment, and is (and should be) subject to revision. That is why plans are best described as "living" documents.

From this point of view, research on how territorial and FRM planning can efficiently and rapidly adapt and change, according to a changing context, is strongly desirable and advantageous. Actually there are many local risk situations where the present norms and regulations do not perfectly match with the actual flood risk conditions. Therefore a tighter collaboration between practitioners and planners would be an important step for bridging the gap between real risk situations and planning.

Moreover a plan should efficiently balance different strategies, according to the uncertainties that affect our understanding of the processes.

The lower is the total uncertainty, the most consistent are the estimation of the risks. Consequently, in these cases, the prevailing strategy in FRM should consider a scenariobased planning, where the risk conditions can be predicted with reliable approximations. This is the case of Dora Baltea river, where either the available data and the understanding of the physical, phenomenological and social context allow a strategy that can be based on flooding scenarios. Revisions of these scenarios are needed, especially after the evidences of recent floods, and the contents of the prevailing strategy (and in particular the types of countermeasures), remain the same.

On the contrary, the higher is the total uncertainty, the less consistent are the results in risk assessment. The prevailing strategy, on its turn, should be based on civil protection countermeasures, including the countermeasures in emergency conditions and after emergence. The 2008 flooding on Garin fan showed that the processes were not perfectly understood. Both the social context (inhabited areas on the fan) and the physical context (the onset conditions and the energies involved) strongly advice the decision maker to consider the limitations of a scenario-based-strategy.

This distinction between these two cases, which are two boundary conditions, is simple in theory but it very difficult in practical applications. Actually, in theory, the two strategies are technically feasible, and can be implemented by decision makers. In practice the researchers, the practitioners, the professionals involved in FRM do not exactly know (or perceive) "how far" their perception/estimation/assessment of risk is from real risk. This cognitive bias is a strong limitation in practical cases, as operators cannot move from 
preconceptions, but instead anchor to them even in light of new data/information. Consequently, in practice, the choice of the prevailing strategy that should be adopted is not always straightforward.

Future works should focus on the application field of the two strategies, considering the relationship between the (theoretical and practical) effectiveness of the FRM strategy vs the uncertainty in the description of the hazards. Also scientific investigation should pay more attention on identification (and quantification) of uncertainty, instead of celebrating the results obtained in very particular cases. Actually, in many scientific investigations, the perfect match between computed results and observed data sometimes can give the false impression to be "perfectly right", causing an overestimation of the available scientific instruments: software, measurement systems, laboratory investigations. On the contrary, it should be taken into account that often, in a changing context, our knowledge can reveal to be inappropriate.

Finally we should think of dealing with uncertainty of flood risk in long-term planning as a process prone to interruption, irrelevance for ongoing decision making, and post-disaster politics. This is efficiently reported by (Floodsite, 2005): "Long-term planning, as strategic planning (Bryson 2004), is prone to be interrupted because of decision makers shifting their attention to pressing problems of the day (...). Usually, elected politicians and citizens have much more on their agenda than long-term planning in flood risk management". This is a non-scientific, but crucial aspect in FRM strategies, which can also imply the necessity to a cultural change in risk management.

\section{Acknowledgments}

It is a great pleasure to thank prof. Bianco of the Politecnico of Turin for his continuous suggestions and hints in this wide and interesting filed of research. I am grateful to Dr. Villacis of UNDP, Dr. Abrate and Dr. Teruggi of the WMO, for the precious documentation and the kind invitations in their activities and debates; to Dr .Arattano, Dr. Luino and Dr. Giordan of the CNR-IRPI of Turin for the documentation of the 2008 flash-flood and the useful discussions. Institutional thanks to our Department director Coccolo, who honoured this chapter with his scientific advices, to ing.Ercole for his precious hints and to our supervisor ing. Masoero. Special thanks to my daughter Chiara, who hinted me how to look beyond the appearance of things.

\section{References}

Acanfora, E. (1990). Sigismondo Coccapani un artista equivocato, Antichità viva, Vol.29.

Arattano, M. \& Franzi, L. (2004). Analysis of different water-sediment flow processes in a mountain torrent, Natural Hazards Earth System Science, Vol.4, pp. 783-791, available from:

http:/ / www.nat-hazards-earth-syst-sci.net/4/783/2004/nhess-4-783-2004.html

Arattano, M., Conte, R., Franzi, L., Giordan, D., Lazzari, A. \& and Luino, F. (2010). Risk management on an alluvial fan: a case study of the 2008 debris-flow event at Villar Pellice (Piedmont, N-W Italy), Natural Hazards Earth System Science, Vol.10, pp.999_ 1008, available from:

www.nat-hazards-earth-syst-sci.net/10/999/2010 
Arattano, M., Franzi, L. \& Marchi, L. (2006). On the influence of rheology on debris flow mathematical simulation: a real case, Natural Hazards Earth System Science, Vol.6, pp. 519-528, available from: http:/ /www.nat-hazards-earth-syst-sci.net/6/519/2006/nhess-6-519-2006.pdf

Arcilla, A., Jimi'Nez, J.A. Valdemoro, H.I. \& Gracia, V. (2007). Implications of climatic change on Spanish Mediterranean low-lying coasts: the Ebro delta case, Journal of Coastal Research, 24, ISSN 0749-0208.

Autorità di Bacino dell'Arno (1997) Trasformazione del territorio e sviluppo dell'edificato lungo il corso dell'Arno e degli affluenti (1954, 1993 e 1995), quaderno n.7, available from: http:/ / www.arno.autoritadibacino.it/cont/testo.php?id=37\&biblio=2

Autorità di distretto idrografico del fiume Po (2008). Adozione di Variante del Piano stralcio per l'Assetto idrogeologico - Variante delle fasce fluviali del fiume Dora baltea; deliberazione n.4/2008, available from:

Autorità di distretto idrografico del fiume Po (2006). Caratteristiche del basino del po Autorità di distretto del bacino del fiume Po, available from:

http://www.adbpo.it/download/bacino_Po/AdbPo_Caratteristiche-bacinoPo_2006.pdf

Autorità di distretto idrografico del fiume Po (1998). Direttiva piena di progetto, Institutional committee acts, Italy (in Italian)

Autorità di distretto idrografico del fiume Po (2001a). Piano di assetto idrogeologico - Relazione generale, Institutional committee acts, Italy (in Italian)

Autorità di distretto idrografico del fiume Po (2001b). Piano di assetto idrogeologico - Norme di attuazione, Institutional committee acts, Italy (in Italian)

Autorità di distretto idrografico del fiume Po (2001c). Piano di assetto idrogeologico - Quaderno delle opere tipo, Institutional committee acts, Italy (in Italian

Beven, K. \& Freer, J. (2001) Equifinality, data assimilation, and data uncertainty estimation in mechanistic modelling of complex environmental systems using the GLUE methodology, Journal of hydrology, Vol.249, pp.11-29.

Booker, J.M., Anderson, M.C.n Meyer M.A. (2009). The role of expert knowledge in uncertainty quantification, Proceedings of U.S. Army Conference on Applied Statistics, 2009.

Borga, M., Degli Esposti, S. \& Norbiat, D. (2006). Influence of errors in radar rainfall estimates on hydrological modelling prediction uncertainty, Water Resources Research, Vol. 42

Bovo, S., Forlati, F, Campus, S., Barbero S. (2007) Evaluation and Prevention of natural risks". London, Taylor \& Francis/Balkema

Bryson, J. M. (2004), Strategic Planning for Public and Nonprofit Organizations. A Guide to Strengthening and Sustaining Organizational Achievement, Jossey-Bass, San Francisco.

Claps, P. \& Laio F. (2008). Aggiornamento delle procedure delle procedure di valutazione delle piene in Piemonte,con particolare riferimento ai bacini sottesi da invasi artificiali. VOLUME I:Costruzione e applicazione delle procedure di stima delle portate al colmo di piena, Report of the Dipartimento di Idraulica,Trasporti ed Infrastrutture Civili,Politecnico di Torino,306 pp., 2008, available from:

http://www.idrologia.polito.it/web2/persone/teammembers/claps/pubblicazioni/ 
Chandler, A. D. (1962). Strategy and Structure. Chapters in the History of the Industrial Enterprise, The MIT Press, Cambridge/Massachusetts.

Coccapani, S. (1610) Trattato del modo di ridurre il fiume Arno in canale, National Biblioteque, Florence.

Ducrocq, V., Nuissier, O., Ricard, D., Lebeaupin, C. \& Thouvenin, T. (2008). A numerical study of three catastrophic precipitating events over southern France. Mesoscale triggering and stationarity factors, Quarterly journal of the royal meteorological society, Vol.134, pp. 131-145.

Department of Transportation (2005). Risk Management Definitions, Washington, DC: DOT, Office of Hazardous Materials Safety, 2005.

Department of homeland security (2008) National response plan. available from: http://www.dhs.gov

Disaster Recovery Journal and DRI International. Generally Accepted Practices For Business Continuity Practitioners. 20 Aug 2007

Easterby, S. \& Lysles, M. (2003). Handbook of Organizational Learning and Knowledge Management, Malden/USA, Basil Blackwell.

Environmental Protection Agency (1986). Emergency Planning \& Community Right to Know Act (42U.S.C. 11001 et seq., 1986).

European Commission (2007), Directive 2007/60/EC of the European Parliament and of the Council of 23 October 2007 on the assessment and management of flood risks, available from:

http:/ / ec.europa.eu/environment/water/flood_risk/index.htm

European Environmental Agency (2007). EEA Multilingual Environmental Glossary, Copenhagen, Denmark. Accessed at:

http:/ / glossary.eea.europa.eu/EEAGlossary

Federal Emergency Management Agency (2007) Guide to emergency management and related terms, definitions, concepts, acronyms, organizations, programs, guidance, executive orders $\mathcal{E}$ legislation available from:

http://training.fema.gov/EMIWeb/edu/docs/terms\%20and\%20definitions/Term s\%20and \%20Definitions.pdf

Federal Emergency Management Agency (2007) Alluvial Fan Flooding, available from: http://www.fema.gov/plan/prevent/floodplain/nfipkeywords/alluvial_fan_floo ding.shtm

Federal Emergency Management Agency (1997). Multi Hazard Identification and Risk Assessment - ACornerstone of the National Mitigation Strategy. Washington.

Floodsite (2005). Strategies for pre-flood Risk management, Report Number T13-07-04.

Floodsite (2009). Language of risk project definitions (second edition), Report Number T32-04-01

Franzi, L. \& Bianco, G. (2001). A statistical method to predict debris flow volumes deposited on a debris fan, Physics And Chemistry Of The Earth Part C-Solar-Terrestial And Planetary Science, Vol. 26, No.9, pp. 683-688, ISSN: 1464-1917.

Green, C., Van der Veen, A., Wierstra E., \& Penning-Roswell, E. (1994). Vulnerability Refined: Analysing Full Flood Impacts. In Floods Across Europe: Flood Hazard Assessment, Modelling and Management. Eds. Edmund Penning-Roswell and Maureen Fordham. London: Middlesex University Press: 32-68.

Grubbs, F. E. (1969) Procedures for detecting outlying observations in samples. Technometrics, Vol.11, pp.1-21. 
Hall, J.W., Weadowcroft, I.C., Sayers, P. \& Bramley, M. (2003), Integrated Flood Risk Management in England and Wales, Natural Hazards Review, Vol. 4, No. 3, pp. 126135.

Hooijer, A., Klijn, F., Pedroli B, \& Van Os, A. (2004). Towards Sustainable Flood Risk Management in the Rhine and Meuse River Basins: Synopsis of the Findings of IRMASPONGE, River Research and Applications, Vol. 20, pp. 343-357.

Hutter, G. (2006), Strategies for Flood Risk Management. A Process Perspective, In: Flood Risk Management . Hazards, Vulnerability and Mitigation Measures, Schanze J., Zeman E., Marsalek J. (eds.), pp. 229-246, Springer, Berlin,.

Kersting, N.F. (2008). Changes in flood management strategies over time. Unesco-IHE website, available from:

http://www.unesco-ihe.org/Flood-Management-Education-Platform/Flood-Modellingfor-Management2/Changes-in-Flood-Management-Strategies-over-Time

Klaus J, Pflügner W, Schmidtke R F, Wind H., \& Green C (1994). Models for Flood Hazard Assessment and Management, In: Floods across Europe. Hazard assessment, modelling and management, pp.67-106, Penning-Rowsell E C, Fordham M (Hrsg.).

Klijn, F., Samuels, P., Van Os A., (2008). Towards Flood Risk Management in the EU: State of affairs with examples from various European countries, Journal of River Basin Management, Vol. 6, No. 4, pp. 307-321.

Kuczera, G. \& Mroczkowski, M. (1998) Assessment of hydrologic parameter uncertainty and the worth of multi-response data, Water Resources Research, Vol.34, No.6, pp. 14811490.

ItalianParliament (1989) act 183/89, published on Gazzetta Ufficiale on 18 may 1989.

International Organization for Standardization (2007). Societal Security - Guideline for Incident Preparedness and Operational Continuity Management, Nr. 22399.

Lollino, G., Mortara, G., Luino, F., \& Giordan, D. (2008). Colata detritica torrentizia in localit'a Garin (Comune di Villar Pellice - TO) CNR report of event, available from: http://www.irpi.to.cnr.it/documenti/CNR-RPI Rapporto\% 20Garin 9\%20giugno \%202008.pdf

Merkel, U. \& Westrich, B. (2008). Pc-river - probabilistic reliability analysis for river dikes, Proceedings 4th International Symposium on Flood Defence: Managing Flood Risk, Reliability and Vulnerability, Toronto, Ontario, Canada, May 6-8, 2008.

Office for public works, Environment heritage and local government (2008) The planning system and flood risk management, Guidelines for planning authorities, rep. n. 20.

Paleocapa, P. (1868). Osservazioni sulla parte idraulica della Legge 20 marzo 1865 per l'ordinamento dei lavori pubblici, Verona; available at: http://archivio.camera.it

Penning-Rowsell, M.A. \& Green, M. (2000). New Insights into the Appraisal of FloodAlleviation Benefits: Flood Damage and Flood Loss Information, Water and Environment Journal, Vol.14, No.5, pp. 347-353.

Pettigrew, A., Thomas, H, Whittington R (eds.) (2002). Handbook of Strategy and Management, London, Sage.

Pettigrew, A., \& Whipp, R. (1991). Managing Change for Competitive Success, Oxford/UK, Blackwell.

Poole M S, Van De Ven A (eds.) (2004), Handbook of Organizational Change andInnovation, New York, Oxford University Press. 
President of the Ministries Council (1990). Decreto published on Gazzetta Ufficiale 4 aprile 1990, n. 79.0

Regione Piemonte (2009), Deliberation n. 2-11830, Regional official bulletin n.34, available from:

http://www.regione.piemonte.it/governo/bollettino/abbonati/2009/34/siste/00 000512.htm (in Italian)

Regione Piemonte (2012). Banca Data geologica, available from: http://webgis.arpa.piemonte.it/bdge/index.php

Ratto, S., Bonetto, F. \& Comoglio, C. (2003). The October 2000 flooding in Valle d'Aosta (Italy): Event description and land planning measures for the risk mitigation, Journal of River Basin Management, Vol. 1, No. 2, pp. 105-116.

Sayers, P. B., Hall, J.W, Meadowcroft, I. C. (2002). Towards Risk-based Flood HazardManagement in the UK, Proceedings of Institution of Civil Engineers, pp. 3642.

Stalenberg, B. \& Vrijling, J.K. (2006). Interaction between Dutch flood protection and urbanisation, Proceeding of the International Symposium of Lowland Technology, Saga, Japan, September, 2006

Tacitus, P.C. (115). Annales, Vol.1, available at: http:/ / www.progettovidio.it/dettagli1.asp?id=1962\&opera=Annali\&libro=Libro\% 20I

Takahashi, T. (1991). Debris flow, IAHR Monograph Series, Balkema,Rotterdam, The Netherlands, 165.

UNDP-DHA (1994). Vulnerability and risk assessement, Disaster management training program, 2nd edition.

UNDRO (1980). Natural disasters and vulnerability analysis, Office of the United Nations Disaster relief Co-ordinator /UNDRO), report of expert goup meeting, 1980.

Varnes (1984). Landslide hazard zonation, a review of principles and practice, UNESCO ed.

Vrijling, J.K., \& Van Gelder, P.H.A.J.M., (1997). The Effect of Inherent Uncertainty in Time and Space on the Reliability of Vertical Breakwaters, Proceedings of the ESReDA Seminar on Industrial Application of Structural Reliability Theory, pp.223-239, Paris, France, October 2-3, 1997

Weather meteorological organization (2007) Economic aspects of integrate flood management, Flood management policy series. APFM, 2007

Weather meteorological organization (2002) Guide on improving public understanding of and response to warnings, report WMO/RTD, no,1139, 2002

Weather meteorological organization (2004) Integrated flood management, Associated program in flood management 2004

Weather meteorological organization (2005) Overview situation paper on flood management practices, Associated program in flood management

Weather meteorological organization (2009) Risk sharing in flood management, Associated program in flood management.

Weather meteorological organization (2006) Social aspects and stakeholders involvement in integrated flood management, Associated program in flood management 


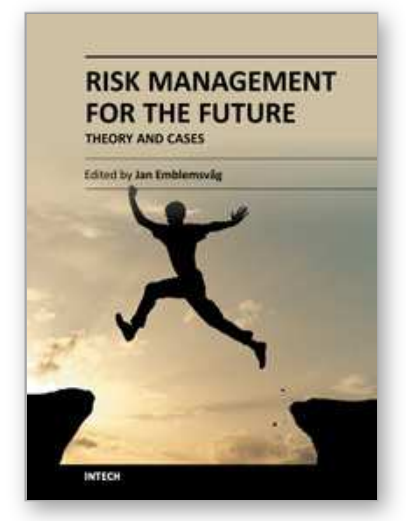

\author{
Risk Management for the Future - Theory and Cases \\ Edited by Dr Jan Emblemsvåg
}

ISBN 978-953-51-0571-8

Hard cover, 496 pages

Publisher InTech

Published online 25, April, 2012

Published in print edition April, 2012

A large part of academic literature, business literature as well as practices in real life are resting on the assumption that uncertainty and risk does not exist. We all know that this is not true, yet, a whole variety of methods, tools and practices are not attuned to the fact that the future is uncertain and that risks are all around us. However, despite risk management entering the agenda some decades ago, it has introduced risks on its own as illustrated by the financial crisis. Here is a book that goes beyond risk management as it is today and tries to discuss what needs to be improved further. The book also offers some cases.

\title{
How to reference
}

In order to correctly reference this scholarly work, feel free to copy and paste the following:

Luca Franzi (2012). Flood Risk Management in Rivers and Torrents, Risk Management for the Future Theory and Cases, Dr Jan Emblemsvåg (Ed.), ISBN: 978-953-51-0571-8, InTech, Available from: http://www.intechopen.com/books/risk-management-for-the-future-theory-and-cases/rivers-and-torrents-floodrisk-assessment

\section{INTECH}

open science | open minds

\section{InTech Europe}

University Campus STeP Ri

Slavka Krautzeka 83/A

51000 Rijeka, Croatia

Phone: +385 (51) 770447

Fax: +385 (51) 686166

www.intechopen.com

\section{InTech China}

Unit 405, Office Block, Hotel Equatorial Shanghai

No.65, Yan An Road (West), Shanghai, 200040, China

中国上海市延安西路65号上海国际贵都大饭店办公楼 405 单元

Phone: +86-21-62489820

Fax: +86-21-62489821 
(C) 2012 The Author(s). Licensee IntechOpen. This is an open access article distributed under the terms of the Creative Commons Attribution 3.0 License, which permits unrestricted use, distribution, and reproduction in any medium, provided the original work is properly cited. 